\title{
4
}

\section{Streetwalkers and Homebodies: Dickens's Romantic Women}

Lennox's and Wollstonecraft's novels, on one level, seem to maintain romance as a consoling realm: their novels seem to set it up as a (woman's) form within which women writers and their heroines can escape or elude constricting power relations. Yet their treatment of romance also reveals the way such power relations trap us all in wishful structures. Such treatment does not only provide a way to attempt to circumvent power; it also allows a way to analyze power, and Lennox's and Wollstonecraft's portrayals of this system emphasize how woman is deployed as a category within and enabling it.

Charles Dickens's novels continue to use women and romance to seem to deny and console. Dickens's work appears to manifest its wishfulness differently from that of the women writers I have analyzed so far; rather than gesturing to some autonomous female realm in his work, the figure of woman and the form of romance become scapegoats whose implication in power suggests autonomy for men and novels. Yet, although such differences seem to point to the difference between male and female writers, their different stakes in constructing women and romance, Dickens's work also breaks down such categories of gender and genre. What his work defines as the feminine and romantic also inhabits it, and reveals its own inheritance within a system of power. 
Dickens's stories take place, critics have long recognized, within the painful and indifferent network of forces in which his characters find themselves and which his novels not only depict but reflect. The interminable and meandering power of Chancery is just one instance of the dim ineluctable oppression that suffuses Dickens's fiction-an oppression needing not so much simply to be revealed (for it is apparent on every page and critics have been accounting for it in psychoanalytic, or economic, or even formal terms for generations) but to be analyzed for the way it operates in and the effect it has on Dickens's work. ${ }^{1}$

D. A. Miller, in a translation of Dickens's world view into a Foucault-inspired rhetoric of power, argues that one tactic of this system of control acted out in Dickens's fiction is that it deliberately presents itself as oppression. Such a presentation strategically implies that this system exists only in its localizable, painful effects: investing one sphere as the site of constraint and control implies that there is a place outside it, a realm of freedom. Yet power, as Foucault has repeatedly defined it, is as much part of what we as its subjects call resistance to oppression (or whatever else that we might perceive as positive and liberating) as it is of oppression itself. The endless and nebulous bureaucratic workings of Chancery trouble the illusion of escape in Dickens's work, such an argument suggests, by revealing that the mechanisms of control are not simply those of clear-cut dominance and force. They are not even locatable because they are part of everything, including the most banal and familiar.

Moreover, the illusoriness of a place outside power is also part of Dickens's story. That prisons are actually inescapable - and that we as subjects carry them with us always (and even gladly) - might stand in as the readily available moral to such novels as Tale of Two Cities, Great Expectations, and Little Dorrit. Dickens's novels analyze, even as they operate within, this system, just as current criticism does, and as readers we inherit much of our contemporary sense of

${ }^{1}$ For the best recent analysis of this indifferent network, see D. A. Miller, The Novel and the Police (1988), 58-106. Dominick LaCapra accuses Miller of thinking the text just uncritically relays such networks without granting them the same access to critique that Miller's own essay implicitly claims for itself; see LaCapra, "Ideology and Critique in Dickens's Bleak House," Representations 6 (Spring 1984): 116-23. 
the individual's lack of autonomy within the system that creates and disposes of it from depictions of it such as those in Dickens. ${ }^{2}$

That Dickens's work must also perform the very operations of power it describes is a truism in a system where not to do so is unthinkable. But that Dickens's work thematizes its own entrapment changes significantly our sense of those operations and how we chart them, if only to make us see the desperation with which his work reacts to such knowledge, the subtlety with which it attempts to manage its predicament, or accommodate itself to it. For all of Dickens's characters do, in one sense or another, struggle (if only to come to terms) with the encompassing network that defines and controls them, no matter how conditional such struggle may be, no matter how necessarily it may backfire. The degree of their ability to evade what their texts set up as inevitable might be one index to what critics have also long recognized as another inherent element of Dickens's novels-the quality of romance within them.

Setting up romance in opposition to power makes romance more than simple idealization or wish. In this chapter I consider how romance becomes for the novel the imaginary locus of dissatisfaction, rebelliousness; it becomes the traditional epitome of that which challenges or escapes restraint, namely, desire itself. The identification of romance with desire-that unsatisfiable "want of something" which Dickens felt propelled him through life-sug-

${ }^{2}$ Despite all Foucault's attention to the positive effects of power (the generative power of life that he discusses at the end of the first volume of The History of Sexuality, for example; see Michel Foucault, The History of Sexuality: An Introduction, vol. 1, trans. Robert Hurley [1980], 135-59), the most effective model of normative power relations remains for him the prison. As he makes the case in Discipline and Punish, the prison occupies a "central position" in the working of power; it provides (what I can hardly escape calling) the governing metaphor for his depiction of our implication as subjects in that power (Michel Foucault, Discipline and Punish: The Birth of the Prison, trans. Alan Sheridan [1979], 308). The centrality of the image of the prison to his own argument suggests that Foucault's analytics of power must inevitably continue to see power on some level as domination (if only by implication through such metaphors) because it cannot magically divest itself of the attitudes and rhetoric it examines. Foucault is aware of this, although critics have argued that that awareness does not make enough of a difference in his practice; see Nancy Fraser, "Foucault's Body-Language: A Post-Humanist Political Rhetoric?" Salmagundi 61 (Fall 1983): 55-70. Although a useful discussion of the way Foucault repeats the gestures he is critiquing, Fraser's essay may oversimplify Foucault's rationale for doing so: it rewrites him in terms of a political pragmatics that winds up, as Fraser admits, looking quite conservative. 
gests too the way romance inhabits whatever attempts to reject and disclaim it. ${ }^{3}$ By constructing transgressive desires as romance-what it is not-the novel makes them other, attempts to disown them. This strategy of displacement and denial provides one way to regulate impossible desires, allowing at the same time a way to indulge them; in being disowned they become safe enough to be allowed to operate.

Such a deployment of romance is similar to the treatment of imprisonment within Dickens's novels, which, even as it localizes that threat, nonetheless recognizes the impossibility of escape. Dickens's attention to form in one of his novels often (conventionally) considered romantic, The Old Curiosity Shop, shows how romance becomes a structural principle in his works, one that rebels against a system set up in terms of constriction and imprisonment by ignoring, deferring, or attempting to unsettle the kind of narrative closure Dickens especially associated with a well-ordered novel. Romance is constructed by the novel as a way to disown the novel's own problems of form, especially those that point to problems of ideology, of being contained within a controlling system of assumptions, representations, and behaviors.

\footnotetext{
3Edgar Johnson, vol. 2 of Charles Dickens: His Tragedy and Triumph 2 vols. (1952), p. 625. I want to emphasize that, in embodying desire, woman is only a scapegoat. The desire associated with her is not essentially hers but patriarchy's projection onto its idea of woman. Woman is simply the traditional-and the most convenient and satisfying - other, but marginal male characters certainly embody this impulse in Dickens too. In The Old Curiosity Shop, the character with the sexiest name, Dick Swiveller, also moves "after a sinuous and corkscrew fashion" (Charles Dickens, The Old Curiosity Shop, ed. Angus Easson [1972], ch. 23, p. 236; all future references [hereafter abbreviated OCS] will appear in the text), and Dick too leads the plot astray: his romance with the Marchioness is a detour from the novel's main story, one so attractive it threatens to split the book in half (Thackeray, for instance, said, "[I have] never read the Nelly part of The Old Curiosity Shop more than once; whereas I have Dick Swiveller and the Marchioness by heart," [from "Jerome Paturot," quoted in Dickens: The Critical Heritage, ed. Philip Collins (1971), 91]). Quilp, that (conventionally romantic) grotesque who embodies the impulse to transgress limits, especially through his sexual power, fittingly succumbs to waywardness gone out of control; the posse that has come to seize Quilp gets lost, and aimlessly circles while he drowns (OCS.67.620). Dickens's other books make sense in these terms as well: Pickwick's book is episodic because Pickwick too embodies desire, if only because he is continually on the run from sexuality. It is the men Dickens offers as typical-exemplars of patriarchy - who do not wander. And just as men can stand for desire, they can also represent (and often do) the conservative power of the home.
} 
In Dickens's work, romance appears as transgression especially through its association with woman, herself like romance displaced and other. Woman is Dickens's emblem for the restlessness of romance, its persistent, uneasy attempts to escape; her wayward roving enacts the narrative disquiet of romance. One persistent motif in Dickens is what Ellen Moers, in another context, has called his "agitating women": those restless, errant women, such as Nell, Nancy, or Lady Dedlock, who roam through his works. ${ }^{4}$ By constructing women as carried away by transgressive desires, Dickens's novels place men on the side of order; his novels construct as male the very englobing system of power that these errant women attempt to unsettle or escape. Rather than denying their own implication within power, then, Dickens's novels displace their own resistance to it in such a way that they (and the male order they represent) can claim control over, or at least associate themselves with, that power.

Yet the very act of managing their own impossible desires by rewriting them through the agency of women and romance exposes what it attempts to conceal: that men and novels don't inscribe others within power but are inscribed within it themselves. The ending of The Old Curiosity Shop, for example, betrays the indifference of the world in which the male order attempts to gain privilege and control, and the price that order must pay even for the illusion of doing so. The accession to power is simply another form of imprisonment, which keeps that group called men orderly and docile within the very system of discipline they attempt to use.

In order to counter or revise such a perception, parallel to the romance of wandering in Dickens's work is that other romance, the romance of the home. Women are not only scapegoated in Dickens's novels for their attempts to escape prison, but women are, paradoxically but accordingly, those inmates most completely imprisoned. The home, women's proper place, is as much as Chancery an emblem of the intrusive permeations of domination and management. And although the home as romance seems opposed to that other romance, wandering - the home representing the very en-

4Ellen Moers, "Bleak House: The Agitating Women," The Dickensian 69 (January 1973): 13-24. I am indebted to her for her brief thoughts on women's walking, both in this essay and in her book Literary Women (1976; 1985), 130. 
closure that wandering seeks to escape-these two romances are actually also similar because their function is the same: the romantic home also consoles the male order, suggesting that women are imprisoned inside it by men. The streetwalker and the homebody turn out not to be all that different.

At the heart of my argument is the contention that, for all their wishful scapegoating of others, Dickens's novels also acknowledge that neither the novel nor the male order can escape the submission and compliance it projects on women and romance. It is perhaps a part of this failure to sustain such a consolation that romance in Dickens's work continues to exercise "an awkward interest (awkward because romantic)," as he calls it in The Mystery of Edwin Drood. ${ }^{5}$ The interest of romance endures, in fact, because of its awkwardness: it does not simply provide Dickens's fiction with a way to manage its desires or identify with the controlling system in which it operates; it also (and awkwardly for that system perhaps, ultimately disrupting its smooth operations, forcing its ever necessary vigilance and constant permutations) repeatedly exposes Dickens's fiction as existing within that system.

The importance of woman in Dickens's work is that she is, like romance, symptomatic: her vicissitudes demonstrate the forces at play in that work. As well as scapegoating her, Dickens's fiction also identifies with her, aligning her romantic character with writing itself. In Dickens's novels, woman becomes an emblem of the way writing, too, is imprisoned within and provides a field for the operations of supervision and control. Yet the treatment of women within Dickens's fiction should also warn that such identification can be only another ploy of dominance. The current struggle for authority within the institution of academic literary criticism, for instance, makes use of such a ploy in its relation to feminism. In this chapter I consider the utility of women in Dickens's worksespecially in The Old Curiosity Shop, Bleak House, and Great Expectations-as well as in current debate. But in unraveling the collapse of different figurations of romance and of woman, I demonstrate that such utility is also always tenuous.

${ }^{5}$ Charles Dickens, The Mystery of Edwin Drood, ed. Arthur J. Cox (1974), ch. 3, p. 53. 
Dickens's contemporaries and early critics unhesitatingly labeled his work as "romance," 6 relying, more or less roughly, on the distinction between romance and the novel formulated long before by Clara Reeve and repeated by Sir Walter Scott in the Encyclopedia Brittanica: a distinction between "the ordinary train of human events," on the one hand, and "wild adventures" and "the marvellous," on the other. ${ }^{7}$ Dickens's work, although taking adventures and marvels in part for its content, also seemed romantic to his critics because of what they agreed on as its major flaw: "The thing which Dickens has yet to do, is to write a good story." ${ }^{8}$ This association of romance with deviations of plot, a link implicit in Scott's contrast of romance with the novel's smooth train of events, influenced Dickens's critics, who saw romance as an error of form in his novels, a quality that disturbed them and needed to be controlled. The trouble with his stories lay in their structure"The plot is invariably his great difficulty"-because they seemed to lack direction, go easily astray. ${ }^{9}$

In faulting those novels, for example, a reviewer of Oliver Twist, confounded by its (lack of) "plot, if it be not an abuse of terms to use such an expression," grounded that novel's structural problems in its romance: "The whole tale rivals in improbabilities those stories in which the hero at his birth is cursed by a wicked fairy and protected by a good one."10 A reviewer of Our Mutual Friend (who titled his review "Mr. Dickens's Romance of a Dust-heap") agreed:

${ }^{6} \mathrm{~A}$ reviewer of Sketches by Boz, for example, proclaimed that from the start Dickens's subject was "the romance, as it were, of real life" (from the Spectator, quoted by Robert Newsom, Dickens on the Romantic Side of Familiar Things: 'Bleak House' and the Novel Tradition [1977], 1). A reviewer of Bleak House found in Lady Dedlock's story "a romance of to-day" (from Blackwood's Edinburgh Magazine, excerpted in Dickens's "Bleak House": A Casebook, ed. A. E. Dyson [1970], 90).

${ }^{7}$ Clara Reeve, vol. 1 of The Progress of Romance through Times, Countries, and Manners, 2 vols. $(1785 ; 1970)$, p. 111; and Sir Walter Scott, "An Essay on Romance," in Chivalry, Romance, the Drama, vol. 6 of his The Miscellaneous Prose Works, 6 vols. (1827), pp. 154-55.

8From Putnam's Magazine, excerpted in Dyson, Dickens's Bleak House, 75.

9Unsigned Review of Bleak House, in the Illustrated London News, in Collins, Dickens: The Critical Heritage, 281.

${ }^{10}$ [Richard Ford], Quarterly Review, in Collins, Dickens: The Critical Heritage, 84. 
Dickens is not happy in plot because "he has sometimes and often devised most unnatural positions and situations"; the reviewer found as much romance in that book as in the "half grotesque and half horrible episodical thread of Miss Haversham" [sic] in Great Expectations. ${ }^{11}$ In such critiques, romance slips over from a problem of content to one of structure.

Such early critics are not alone in tracing a connection between romance and discursive, episodic plot; modern theorists of romance trace this connection too. Northrop Frye has suggested that romance is the form that comes closest to pure story, a vagrant "and-then" form, carried along by its own momentum from one discontinuous event to another. ${ }^{12}$ Patricia Parker also characterizes romance as "a sequential and processional form," but to Parker the sequential remains "within a frame in which presence, or fulfillment, is always in some sense placed at a distance."13 According to Parker, this distant end is what gives meaning to the divagations of romance, what makes them err. But this dynamic of the text which romance lays bare is, Roland Barthes suggests, one element of narrative encoded within every text:" "whereas the sentences quicken the story's 'unfolding' and cannot help but move the story along, the hermeneutic code performs an opposite action: it must set up delays (obstacles, stoppages, deviations) in the flow of the discourse. . . . [It] interrupts the sentence, suspends it, turns it aside."14 For Parker, when this principle becomes marked and takes over, when the delays intensify and the end becomes more open, a text is romantic. Although she differs from Frye in emphasizing an endpoint from which romance's story veers, her focus, like his, is on the process: it is the veering away, the pausing and backtracking, that is romantic. ${ }^{15}$

11 Unsigned Review, in the Eclectic and Congregational Review, in Collins, Dickens: The Critical Heritage, 459.

${ }^{12}$ Northrop Frye, The Secular Scripture: A Study of the Structure of Romance (1976), 47. This spinning out of a tale, according to Frye, is "the romantic element" in works like Little Dorrit and Our Mutual Friend, and such "a sprawling octopus of a plot . . . which we can hardly follow at the time and cannot remember afterwards, seems to be almost an anti-narrative" (40).

13Patricia Parker, Inescapable Romance: Studies in the Poetics of a Mode (1979), 13.

${ }^{14}$ Roland Barthes, S/Z, trans. Richard Miller (1974), 75.

${ }^{15}$ For a thorough discussion of the way narrative forces are in excess of closure and the way resistance to closure generates narrative, however, see D. A. Miller's first book, Narrative and Its Discontents: Problems of Closure in the Traditional Novel (1981). 
In his fiction, Dickens himself implicitly defines romance as a deviating and-then form. One of his Christmas stories, "Mugby Junction," under the running head "A Lesson in Romance" contains the following instruction in the principles of romance: young Polly

commenced a long romance, of which every relishing clause began with the words: "So this," or "And so this." As, "So this boy," or, "So this fairy;" or, "And so this pie was four yards round, and two yards and a quarter deep." The interest of the romance was derived from the intervention of this fairy to punish this boy for having a greedy appetite. To achieve which purpose, this fairy made this pie, and this boy ate and ate and ate, and his cheeks swelled and swelled and swelled. There were many tributary circumstances, but the forcible interest culminated in the total consumption of this pie, and the bursting of this boy. ${ }^{16}$

By the relishing clauses that characterize romance, Dickens primarily means embellishments, but the word "relish" in its root form carries the sense of "to release or relax." The form of romance, its connecting clauses, relaxes the forcible interest of the plot. Tributary circumstances swallow up the culmination, and with relish, just as the boy swallows up the pie. That the romance here transforms and yet is part of a didactic tale-the bursting boy a comic lesson to all greedy children that burlesques the didactic form while engaging in it, much as Dickens's own novels dosuggests the consolatory function of romance: the explosive anticlosure of romance can be placed in service of and made to enforce a particular agenda.

\footnotetext{
Miller's more recent work on the novel reconsiders the deconstructive and psychoanalytic tendency of this earlier work.

16Charles Dickens, "Mugby Junction," in Christmas Stories, vol. 32 of The Gadshill Edition of the Works of Charles Dickens, ed. Andrew Lang, 33 vols. (1897-99), p. 164; this edition hereafter abbreviated The Works. For the linking of women and romance through pie in Dickens, see "Nurse's Stories," in The Uncommercial Traveler, vol. 29 of The Works, pp. 176-80; and "The Holly-Tree," in Christmas Stories, vol. 31 of The Works, pp. 123-24. Dickens gives us different versions of a sinister romance of a pie that he heard as a baby from his nurse. Her narration of romances links women with the form but so does the content of this particular romance: in "Nurse's Stories," Captain Murderer, after his various wedding nights, bakes his brides into pies and happily eats them.
} 
The formal release and dissipation of romance carry with them sexual associations, and, following Barthes, Parker ties this structural understanding of romance to an erotics of the text:

The suspensions which for Barthes become part of an erotics of the text recall not only the constant divagations of romance and its resistance to the demands of closure, but also the frustration . . . of what Barthes calls the teleological form of vulgar readerly pleasure - the desire to penetrate the veil of meaning or to hasten the narrative's gradual striptease-by a continual postponement of revelation which leaves the reader suspended, or even erotically "hung up."17

Such an erotics is often grounded in the figure of a woman, a seductress teasing toward yet delaying consummation, endlessly desirable because unavailable, and who, like the boy, is ultimately often sacrificed too, extinguished by what are constructed as her own desires.

The Arabian Nights Entertainment, or The Thousand and One Nights, is the premier example of romance as an endless drifting story manifested in a woman's devious leading on. A labyrinth of digression, this story slides on and on-a thousand and one nights. The teasing provocativeness of the Arabian Nights is figured in Scheherazade, who stands in for the text itself, is the emblem of its romance: Thackeray's collusion of the two, for example-he hopes all "have found their romancer-their charming Scheherazade" is typical. ${ }^{18}$ Scheherazade too is threatened with extinction, which she must put off, and her romance connects the coyness of women and of plot: the popular (mis)conception of Scheherazade's story, owing partly to bowdlerized translations and partly to an inevitable logic, is that she puts off sexual as well as narrative climax from night to night. And the Arabian Nights was one of Dickens's favorite romances. As he revealed to John Forster in his autobiographical

17Parker, Inescapable Romance, 220-21.

${ }^{18}$ William Makepeace Thackeray, "De Juventute," in Roundabout Papers, vol. 22 of The Charterhouse Edition of the Works of William Makepeace Thackeray, 26 vols. (1901), p. 79. Quoted by Margaret Annan, "The Arabian Nights in Victorian Literature" (Ph.D. diss., Northwestern University, 1945), 54. 
sketch (later included in David Copperfield) it was one of the books of his childhood that formed his imagination. ${ }^{19}$

In Dickens's most extended frame-tale, The Old Curiosity Shop, the formal waywardness of romance and its connection through women to desire become most clear. This work too is a tale prompted and prolonged by desire-Quilp's for little Nell, Dickens's for Mary Hogarth. George Gissing called Nell "a child of romance,"20 and that her death is necessary for the novel to end shows not just that she stands in for its romance (by ending her rambles the novel short-circuits the detours of romance) but also that she exposes the purpose that romance serves: Nell's sacrifice to the closure of the novel suggest the way it needs to project out, to pursue and kill off, what are really its own dissatisfactions with closure and all that closure implies. The male order projects its own dissatisfactions with order onto a woman so that it can indulge these feelings at a distance, converting its own discomfort and even disturbing rebelliousness into a form that is displaced and manageable. By ultimately killing the woman off, that order seems to get rid of its dissatisfactions. In The Old Curiosity Shop, such romantic impulses are managed and controlled at a still further remove: contained within a frame that is governed by the appropriately named Master Humphrey. Such structural complexity suggests the elaborate lengths to which the narrative seems pushed in its endless compromises. It suggests too the overkill with which it meets the threat represented by women's desires.

The Old Curiosity Shop grew out of Dickens's weekly periodical, Master Humphrey's Clock. The governing conceit of Master Humphrey's Clock was a club, whose members met to read tales to each other. This governing story provided the periodical with a frame, a narrative device of lasting interest for Dickens, as his Christmas stories illustrate. The frame intrigued him because, as

${ }^{19} \mathrm{John}$ Forster, vol. 1 of The Life of Charles Dickens, 3 vols. (1872), p. 9. George Gissing also found it the most important romantic influence on Dickens's writing; see George Gissing, Charles Dickens: A Critical Study, vol. 20 of The Standard Edition of the Works of Charles Dickens, 22 vols. (n. d.), pp. 29-30. See also Annan, "The Arabian Nights," 201-2.

${ }^{20}$ Quoted by Loralee MacPike, "'The Old Cupiosity Shape': Changing Views of Little Nell, Part I," Dickens Studies Newsletter 12 (June 1981): 37. 
he said of Master Humphrey's Clock, it supplied an "almost inexhaustible field" for him to mine, linking together wildly discontinuous events without the novel's demand for unity, and, in his early plans for the periodical, Dickens drew his ideas of its form directly from that framed tale, the Arabian Nights. ${ }^{21}$ Yet although Dickens designed Master Humphrey's Clock precisely for its discontinuity, that very quality seemed to worry him. Would the work have any point or interest? He considered heading it with a quotation from the Spectator, promising "to give it over, as soon as I grow dull," 22 and as early as the first installment, he was bothered by what some of his critics characterized as "the article's slow pace and lack of incident." 23 According to Forster, Dickens's concerns were justified; his audience was bothered by the disunity of the work: "with the discovery that there was no continuous tale the orders at once diminished." 24

The Old Curiosity Shop was introduced in order to bring Master Humphrey's Clock into line. In search of a narrative to contrast with the frame, Dickens inserted what was at first meant to be a short tale and, immediately after including "the little child-story," 25 as he called it, wrote to his publishers that he had begun "to give [Master Humphrey] a less discursive appearance." 26 The Old Curiosity Shop was designed to oppose the "discursive," which in its root sense means "to run to and fro." In the preface to the completed novel, Dickens's relief in its unity and directedness is apparent: "The first chapter of this tale appeared in the fourth number of MASTER HUMPHREY'S CLOCK, when I had already been made uneasy by the desultory character of that work. . . The commencement of a story was a great satisfaction to me" (OCS.Preface.41). Dickens's assumption is that the nature of The Old Curiosity Shop as story-as a "child-story" that grows up to be a novel-necessarily gives it focus and closure. Perhaps it is because this novel was originally

\footnotetext{
21For the "inexhaustible field," see "To John Forster [14 July 1839]," in vol. 1 of The Letters of Charles Dickens, ed. Madeline House, Graham Storey, and Kathleen Tillotson, 6 vols. (1965-), p. 564. For mention of The Arabian Nights, see "To John Forster, [14 July 1839]," in Letters, 1: 564 .

22"To John Forster, 13 September 1840," in Letters, 2: 127 n3.

23"To W.C. Macready, [29 January 1840]," in Letters, 2: 13 n3.

${ }^{24}$ Forster, Life of Charles Dickens, 1: 179.

25 "To John Forster, [?8 March 1840]," in Letters, 2: 40.

26"To Messrs. Chapman \& Hall, [9 March 1840]," in Letters, 2: 41.
} 
conceived to give aimlessness a focus that it becomes such an endobsessed story; the end of Nell's story must be the definitive end, death, to overemphasize its function as well as overcompensate for its failure to fulfill that function.

For fail it does; the romantic episodic quality of Master Humphrey's Clock also infects this novel; it too rambles and digresses. Contemporary critics immediately questioned its unity and closure. One thought that the novel was "without much elaborateness of plot, or apparently fixedness of purpose in the mind of the author."27 Dickens answered, "I never had the design and purpose of a story so distinctly marked in my mind, from its commencement." But he admitted, "I know a great many people are of [your mind]."28 Forster, too, thought the novel involved "less direct consciousness of design on [Dickens's] own part than I can remember in any other instance of all his career, ${ }^{29}$ and this judgment survives to this day, echoed by critics such as Edmund Wilson, who find it "an impromptu yarn, spun out." 30

Yet Dickens's disclaimers against romantic restlessness screen its attraction for him. Modern critics also note the animating importance of romance in Dickens's work. John Kucich argues that "what Dickens meant by Romance ... would seem to be, quite simply, energy"; Elaine Showalter suggests that for Dickens, "this ceaseless activity and motion, for all he paints it dark, is the source of life and human values." 31 Although readers may question the humanist idealization implied in the triumph of "life" that such upbeat formulations express, romance remains a necessary-and necessarily denied-element permitting the operation of Dickens's delicately balanced fictional system.

The Old Curiosity Shop announces its own romantic discursiveness by opening with a "ramble" (1.44). Master Humphrey, on one of his idle nightwalks, runs into Nell, who has lost her way, and he returns her to it by the most devious and intricate route

27"To Thomas Latimer, 13 March 1841," in Letters, 2: 233 n4.

28 "To Thomas Latimer, 13 March 1841," in Letters, 2: 233.

${ }^{29}$ Forster, Life of Charles Dickens, 1: 178.

${ }^{30}$ Edmund Wilson, "The Two Scrooges," in The Wound and the Bow: Seven Studies in Literature (1947), 18.

${ }^{31}$ John Kucich, Excess and Restraint in the Novels of Charles Dickens (1981), 193; Elaine Showalter, "Guilt, Authority, and the Shadows of Little Dorrit," Nineteenth-Century Fiction 34 (1979): 27. 
(1.46). Such a proliferation of indirection calls attention to itself, setting the stage for the rambling of the rest of the novel. With Master Humphrey's disappearance from the novel-perhaps he can disappear precisely because of this-Nell inherits his aimless, peripatetic motion. When she meets Master Humphrey at the very beginning of the story, she is lost, implying that she has a direction; yet, after his exit, when she flees London with her grandfather, she too becomes an aimless wanderer. This emphasis on random walking renders literal the romantic "discursive" character of the book. Moreover, this master's immediate obsession with and assumption of authority over Nell set up woman's attraction and usefulness for the patriarch(y): he loses Nell within mazes that he himself supposedly controls-both the deliberately confusing path he guides her through and the story he tells about her. She takes over his random motion, making it a woman's problem, set up in such a way that he has power and control over her and over it.

This romantic impulse is an important element in the book because it strings out even as it leads up to satisfying the demands of closure. Romance catches up the plot in its own movement and makes it heedless of its goal, just as, during Kit's journey to find Nell, despite his hope and anxiety for what lies at journey's end, he finds himself as he hurtles toward that end hypnotized by the twistings and turnings of the "road itself" so that everything collapses into that road: "a wall, a ruin, a sturdy gable-end, would rise up in the road; and when they were plunging headlong at it, would be the road itself" (70.640). The Old Curiosity Shop continues the digressions and wanderings of Master Humphrey's Clock, prolonging the very resolution it was meant to create; Dickens admits: "I am breaking my heart over this story, and cannot bear to finish it." ${ }^{2}$ To justify drawing out Nell's death, he tells Forster: "I only began yesterday, and this part of the story is not to be galloped over, I can tell you. . . . I tremble to approach the place a great deal more than Kit." ${ }^{\prime 3}$ He takes care to suggest that The Old Curiosity Shop never really does end. The book continues after its conclusion as a tale of little Nell that Kit repeats again and again to his children, just as

32 "To George Cattermole, [?22 December 1840]," in Letters, 2: 172.

33"To John Forster, [?8 January 1841]," in Letters, 2: 181. 
Master Humphrey is telling us that tale now. ${ }^{34}$ Dickens neatly sums up the tension between romantic perpetuation and novelistic resolution in his metaphor for the writing of Master Humphrey, the winding of Master Humphrey's clock. "Wind, wind, wind, always winding am I," he writes; "and day and night the alarum is in my ears, warning me that it must not run down." 35 The notion of winding catches the doubleness between the novel and romance in Dickens's writing - "to wind up" means to finish as well as to keep going, and Dickens's fiction works because it can swing back and forth between the two.

The swing of this pendulum is especially effective because of the figure caught below it. The Old Curiosity Shop is Nell's story; her "image sanctifies the game" (31.306), and, modern prejudice aside, Dickens meant readers of the book to be like the inquisitive landlady in the story, "who had a great curiosity to be made acquainted with every particular of Nell's life and history" (46.433). ${ }^{36}$ Her story is one of romantic deferral, the deferral of her death; her wanderings through the countryside draw out that death and emblematize the structural principle that the novel claims to suppress while indulging it. Such deferrals diffuse the blame for that death-for Nell ultimately does die, of course, and despite the (self-interested)

\footnotetext{
34The bachelor's letters to Mr. Garland are also installments of the novel in miniature: "he had dwelt upon them from first to last, and had told there such a tale of their wanderings, and mutual love, that few could read it without being moved to tears" (OCS.68.628-29).

35 "To Walter Savage Landor, 26 July 1840," in Letters, 2: 106.

36The landlady's curiosity, in a text entitled The Old Curiosity Shop, might be seen as an example of how a pernicious surveillance sets up the realm of the ordinary. Significantly, the responsibility for such monitoring is deliberately shifted to a woman (and to the domestic - she is a landlady, a professional homebody - a category about which I will have something to say later in this chapter): the landlady herself admits "curiosity you know is the curse of our sex, and that's the fact" (OCS.46.433). The landlord's response to her statement ("The landlord scratched his head, as if he thought the curse sometimes involved the other sex likewise" [OCS.46.433]), in its ambiguity, catches the doubleness of Dickens's attitude: on the one hand, perhaps, his response seems to imply that the consolation of scapegoating doesn't quite work-men do remain curious, however much they blame women for it - at the same time it implies that it does work-men aren't curious; women's curiosity is to blame for getting men in trouble, "involving" them in something of which they are innocent.
} 
denials of the literary fraternity of Dickens's time, Nell's name, at least, implies that her death is built into her very characterization from the beginning - and, by diffusing it, allow reader and narrator to enjoy it without feeling too complicitous in it.

That the male order may be culpable for her death is actually important to its claims, since such control over her might attest to male power. Such power over romantic women is carefully figured, directed away from aggression and violence, and supported instead by that well-worn bedrock, men's sexual power over the inferior sex. Nell's supposed leading on toward a desired consummation, and yet her teasing away from it, suggest the way such anxious desires get localized as sexuality. It's no accident, for example, that Master Humphrey's eyes light right away on Nell's bed in the old curiosity shop; similarly, an early illustration of Nell has her lying in it, and her death ultimately fixes her there for good. Quilp's pursuit of Nell, which drives her there, highlights one aspect of this sexuality. It recalls the biographical story of Dickens's own enduring longing for his sister-in-law, who died in his arms. The biographical debate about Mary Hogarth largely agrees on her relation to The Old Curiosity Shop; in that novel, Dickens's guilty desire for his wife's sister-guilty both because illicit and because he felt it caused her death-are figured by Quilp's pursuit of Nell, which also ends in her death(bed). ${ }^{37}$ But whatever feelings of remorse such stories imply are equally matched by their celebration of male sexual power. Quilp's own death may be a punishment for his desire, but it also figures its power (a power emblematized by Quilp's burning red cigar [4.82-83]), for Nell dies after him, as if his desire has given her life, kept her going. She is the ground on which that desire plays.

At the same time, however, the book suggests that Nell must, according to idiomatic logic, be lying in a bed that she herself has

37For a discussion of the critical debate about Mary Hogarth's influence, see MacPike, "The Old Cupiosity Shape,'" and also Michael Steig, "The Central Action of 'The Old Curiosity Shop,' or Little Nell Revisited Again," Literature and Psychology 15 (Summer 1965): 163-70. Steig's statement that when Nell's death finally comes, it is a relief, for "like the rape of Clarissa, it's good to have it over" (167), not only illustrates that that death is sexualized but betrays the function of such sexualizing for its (male) audience: it provides (or ought to) an easy sacrifice of woman to design, a way of stopping dead the trouble she causes. Such readers want to cry: "The deed is done; the novel lives!" 
made. Nell is more than "pure as the newly-fallen snow" (72.658), more than a blank white ground on which male appetite can be projected. Certainly Nell seems the best example in Dickens, if not in English literature, of the absolute denial of any active female sexuality. Yet Dickens's attempts to deny Nell even gender, his harping on her status as child rather than young woman-or even the fourteen-year-old girl he says she is-also seem excessive, overdetermined denials.

We can see the connection of Nell's wandering and her sexuality at that epitome of morally dubious motion, the racetrack, in her first attempt at begging:

There was but one lady who seemed to understand the child, and she was one who sat alone in a handsome carriage, while two young men in dashing clothes, who had just dismounted from it, talked and laughed loudly at a little distance, appearing to forget her, quite. There were many ladies all around, but they turned their backs, or looked another way, or at the two young men (not unfavourably at them), and left her to herself. She motioned away a gypsy-woman urgent to tell her fortune, saying that it was told already and had been for some years, but called the child towards her, and taking her flowers put money into her trembling hand, and bade her go home and keep at home for God's sake. (OCS.19.213-14)

The erring woman, alone in her carriage, emphasizes the inherently sexual nature that Dickens's work accords to woman's independent motion, but the distinctive suggestion of this tableau is this woman's responsibility for her fortune. She has not been acted on so much as she herself has acted, as the other ladies, ignoring her but gazing approvingly at the young men, suggest; their desire for the men highlights and repeats what they profess to condemn, what once must have been the fallen woman's own favorable glances, her active desire. Nell, as passive and innocent mirror of male desire, is not the only model for female sexuality in the book. Moreover, Nell's innocence is in question: that this strayed woman is the only one who understands Nell, and that her plea to her is so desperate, suggest a greater identification than that she was once penniless too; there is more of a similarity between them as fellow travelers. Nell's very agitation (she trembles), given its context, 
heightens the identification. It is a gesture drawn from the Victorian stock of conventional sexual markers-trembling can signal desirability and desire.

Nell's death demonstrates that the male order needs a category of female sexuality because it needs to project and drive out its own ultimately unsatisfied (because unsatisfiable) desires. Quilp's death marks the violent extinction of just such desires. Projecting sexuality onto Nell, and then killing her, is a way of leaving men with only diffused and negotiated desires, purged of all the insurgent force this text characterizes as monstrous-Quilp-like-and, hence, needing to be conquered. The erotic recompense of Nell's death scene (and critics have long pointed to its sexual charge) is denied to the malcontent, Quilp, but is, telling, given to a boy and a group of old men, as if a reward for their very powerlessness. They are reanimated by it, but not threateningly, just as are the group of living dead who gather at Nell's graveside (72.657-58).

The single gentleman's unmasking at the end of the book seems to emphasize that Nell's sacrifice is meant to profit the world of men, for her deathbed gathering brings about the reunion of the younger and elder brothers. But that reunion is an empty one; the reader is told the grandfather never does actually acknowledge his brother (72.66o). Similarly, it is hard to accept that that brother is also Master Humphrey, an identification that is not so much a failed overelaboration of the story as it is a reiteration of the impossibility of the very identifications-bonds-Dickens's story tries to foster. The conventional climactic recognition scene never comes off, disturbing the closure of the novel, and upsetting both the identification of the male order with such regulating novelistic desires and its identification of such devices with power. Overturning closure or putting it into question does not provide a realm of freedom in The Old Curiosity Shop; the only realm Dickens can imagine for that is death, a pyrrhic victory indeed, for he fails to imbue Nell's death with any transcendent meaning, as he was the first to admit. ${ }^{38}$ The saving and life-giving relations (between men) that the male order imagines for itself remain unrealized within the novel, only a fantasy of "consol[ation]" (71.651) that the younger brother seeks for the vio-

\footnotetext{
38Dickens writes: "I can't preach to myself the schoolmaster's consolation [that death has meaning because 'good deeds' come from 'dusty graves'], though I try"; "To John Forster, [?8 January 1841]," in Letters, 2: 181-82.
} 
lence and indifference of his world. That Dickens figures this younger brother as Master Humphrey, a weak and misshapen cripple, suggests just how ironic and muted is his novel's sense of men's mastery in this world.

Closure is complicated within Dickens's work because it recognizes closure not just as completion and unity but also as (what is implied in its root meaning)enclosure, barring, imprisonment. Kit's imprisonment, one among many in Dickens's fiction, offers a clear example of the sense of enclosure and constriction that suffuses the world of that fiction. While in prison, Kit dreams "always of being at liberty, and roving about, now with one person and now with another; but ever with a vague dread of being recalled to prison; not that prison, but one which was in itself a dim idea, not of a place, but of a care and sorrow; of something oppressive and always present, and yet impossible to define" (61.556-57). Similarly, Pip, in a novel overshadowed by the bulk of Newgate prison, characterizes his education in the law of his fathers as the heavy obligation of what he calls to "walk in the same all the days of my life." 39 It is as a "thick curtain . . . [falling] on all interest and romance" and "never," he reports, "has that curtain dropped so heavy and blank, as when my way in life lay stretched out straight before me" (GE.14.135). This vision that the very passage through life is a prison itself accounts for the melancholy of Great Expectations, its resigned acceptance that we must convert our great expectations into common unhappiness. ${ }^{40}$ Pip learns that the romance of his life is illusory, and the bleak path leading from the forge is the best and only way.

The common unhappiness that pervades Dickens's fiction becomes just another of his conservative ideals expressly because it is not shared in common; it is denied, or at least made bearable, at the expense of others. The heavy obligations of conscience that pain Pip when he strays from the path of virtue remind him of another rigidity: "Conscience is a dreadful thing when it accuses man or boy; but when, in the case of a boy, that secret burden co-operates with another secret burden down the leg of his trousers, it is (as I can

${ }^{39}$ Charles Dickens, Great Expectations, ed. Angus Calder (1965), ch. 7, p. 73; all future references to this book (hereafter abbreviated $G E$ ) will appear in the text.

${ }^{40}$ As suggested by Freud, "The Psychotherapy of Hysteria," in vol. 2 of The Standard Edition of the Complete Psychological Works of Sigmund Freud, trans. James Strachey, 24 vols. (1953-74), p. 305; this edition hereafter abbreviated SE. 
testify) a great punishment" (GE.2.44). Literally that burden is the piece of bread Pip has secreted for Magwitch, but the doublesexual and legal-senses of "testify" point to a crucial link between Pip and the convict, who is also a "man with a load on his leg" (2.45). Magwitch's awakening of Pip to his own guilt and complicity within the structures of power and imprisonment is inherently associated with sexuality. Dickens's novels reduce the system of power relations to the romantic vagaries of sexual relations because sexual relations can be hierarchized. The reduction wishfully aligns authority once more with men. Moreover, those subjects in the supposedly privileged male position don't simply feel that the loads upon their legs are burdens. As Freud notes in "Medusa's Head," rigidity that looks like a punishment can also be felt as apotropaic, a man's reminder to himself of his own power. ${ }^{41}$ That Pip's phallic burden "co-operates" with his conscience, with the self-regulating power that aids in constraining and imprisoning desire, suggests an urge not just to elude and wander from, but to identify with and control, that power.

The opposition between the straightforward march to closure and the deferrals of wandering is constructed and strategic, just as are those set up between men and women, or the novel and romance. The insistent restlessness inhabiting The Old Curiosity Shop suggests that such indirection is really no different from any more straightforward path; the first page of the novel shows that such detours, rather than leading to freedom, carry their own sense of oppression. Dickens, in an image that sets the tone for the novel, has Master Humphrey imagine the thoughts of a sick man, cut off from the world but forced to listen to it parade past his window: "that constant pacing to and fro, that never-ending restlessness, that incessant tread of feet" depict "the stream of life that will not stop, pouring on, on, on" (OCS.1.43). The novel emphasizes that such movement is much more a prison to the man forced to listen to it than the quiet grave in which he will ultimately lie. The grave, in fact, seems the only escape possible, and Dickens ironically poses this sphere, with its meaningless autonomy, to the self-perpetuating system from which it delivers us, contrasting "those who lay so

41Freud, "Medusa's Head," SE, 18: 273-74. 
still beneath the moss and turf" with the "old restlessness" and "the useless strife in which they had worn away their lives" (17.187). In its grimly insufficient way death remains the culmination of Dickens's novel too, remains the only means of rescue for Nell from her imposed and oppressive wandering.

The agent of that wandering, Nell's grandfather, epitomizes the relation of the novel to her. Claiming to love and consider her in all that he does (and Master Humphrey, as spokesman for the book, insists the reader believe him: he "never doubted that his love for her was real" [1.55]—an insistence that helps demystify the attitudes and behaviors commonly called love, revealing that it too can be a tactic), her grandfather uses Nell as the excuse for his unacceptable desires-specifically his obsession with gambling, an activity that might be a metaphor of the book's logic, a desire that not only feeds on its own exercise but expects reward and privilege simply because it wants them. Nell is supposed to sanctify that game in particular. Not only does Nell's grandfather exploit her in pursuit of it and his own interests, but he expects her to care for him all the while. Although the book condemns his attitude-his question, "What would become of me without her?" (27.273) meets with Mrs. Jarley's sharp rebuke for its selfish reversal of roles-such condemnation serves the purposes of the novel and is of no real aid to Nell. Instead, the novel presents the grandfather's blind and selfish treatment of her as diseased and extraordinary in order to screen its own complicity with it, its own reliance on such treatment as one of the rules of its own game.

Yet even the grandfather, who operates by scapegoating Nell, sometimes seems shocked into recognizing his (mis)use of her: even he pauses in the midst of blaming her for the "close eternal streets" through which they wander, of berating her for keeping him from the gambling that provides the fantasy of an impossible route out of those streets, even he stops to cry " 'Ah! poor, houseless, wandering, motherless child! . . . has all my agony of care brought her to this at last!' " (44.415). Yet the identification of Nell's wandering with her houselessness suggests that such a complaint is also in part as self-interested as the rest of the grandfather's perceptions. It points, in fact, to another kind of romance and another kind of consolation within Dickens's fiction.

Dickens's best-known statements about romance come in "A 
Preliminary Word" to his periodical Household Words and in the Preface to Bleak House. One of the goals of Household Words is "to show to all, that in all familiar things, even in those which are repellent on the surface, there is Romance enough, if we will find it out." 42 In the Preface to Bleak House, Dickens likewise asserts that, in that novel, he has "purposely dwelt upon the romantic side of familiar things." 43 As the titles Bleak House and Household Wordsand as Dickens's claim that he is "dwelling" on romance-suggest, Dickens's emphasis on the familiar becomes a romance of the home, the domestic circle that his works most closely associate with women. Household Words was particularly meant for women-a family magazine, which catered to housewifely interests and educationand Bleak House is in large part a celebration of women's home virtues: the prefaces to both announce Dickens's domestication of romance. Domestication, as its etymology suggests, is never very far from dominion; the home (domus) always presupposing its master (dominus).

That this home is meant to be a sanctuary from wandering, and from the dissatisfactions and longings that wandering entails, the scene at the racecourse, when the fallen woman bids Nell "go home and keep at home for God's sake," already implies. To the streetwalkers who travel his novels, Dickens opposes that overtly romanticized sentimental stereotype, the tranquil Angel in the House, who is seemingly untroubled by sexual desire. Throughout his work, he deploys the home to coopt romantic movement: Dickens's paean to home midway through The Old Curiosity Shop explicitly stops the forward movement of his story (Dickens introduces this praise with "Stay" [38.362] and "let us linger in this place" [38.363]). Similarly, a character in Pickwick tells us "there's romance enough at home without going half a mile for it," a statement that might be the moral to Bleak House. ${ }^{44}$ In that novel, Dickens directly sets the repose of the fireside against outside bustle. Jarndyce points the contrast between home and active life, identifying home life with women

${ }^{42}$ Charles Dickens, "A Preliminary Word," in Miscellaneous Contributions, vol. 19 of The Standard Edition of the Works of Charles Dickens (n.d.), p. 3; this volume hereafter abbreviated Misc.

${ }^{43}$ Charles Dickens, Preface, Bleak House, ed. Norman Page (1971), 43. All further references to this work (hereafter abbreviated $B H$ ) appear in the text.

${ }^{44}$ Charles Dickens, The Posthumous Papers of the Pickwick Club, ed. Robert L. Patten (1972), ch. 21, p. 361. 
and reserving the active life for men, when he separates Ada and Rick: "She remains here, in her home with me. Love her, Rick, in your active life, no less than in her home'" (BH.13.232-33). ${ }^{45}$ The home is almost the manifestation of formal closure in Dickens even more emphatically than in other novelists, the notoriously sentimental setting up of housekeeping at the end of his stories marking their culminations and resolutions.

The opposition between restless activity and stable home is meant to hide their similarity, to hide that they both serve the same consoling function. But if the home is reassuring in Dickens's work, it is not just because, as D. A. Miller suggests, Dickens uses it to represent the exemplary autonomous sphere outside the network of control. Rather, the home also attests to that network and its oppression. Despite the generous complications of his argument, Miller's conclusions - that the home and family are the banal embodiment of the same indifferent disciplinary system embodied in oppressive public institutions-restate what Dickens's novels, and feminist readers of them, have already said: that the home is a prison. The home is consoling to the male order, because it traditionally constructs the home as the woman's sphere, her proper place. Just as it serves the male order to represent the dissatisfactions of its desire as women's problem, and so displace and indulge them, it also reassures that order to transfer its awareness of its own oppression and imprisonment onto women. It achieves such a transfer by emphasizing women's inescapable imprisonment and confinement within the domestic, within the ordinary and insuperable details of daily life.

Bagnet's motto- "Discipline must be maintained" (BH.66.930)then does not so much refer to the family's voluntary policing of all its subjects, as Miller has claimed, as it focuses that attention on the women within the family, whose peculiar servitude is what Bagnet actually demands when he says it, no matter how comically or ironically that demand is presented. Bleak House indeed presents Mrs. Bagnet's seeming autonomy, and even authority, as comic grotesquery, benign because clearly understood as comic, a reversal

\footnotetext{
45Yet, in keeping with the subversion in Dickens's writing of its own explicit ulterior romanticism, this distinction is an imposed one that the novel breaks down: Esther, for example, despite her praise of home duties, actually travels quite a bit (I am indebted to Margaret Berg for this observation).
} 
of (what the novel believes ought to be) women's actual domestic subjection. Part of and attesting to the force of that subjection is that women do not necessarily accept it voluntarily and do not find it so benign. They are not as happy in it, for example, as is Nell's bird in its cage: the contrast of that lively caged bird with Nell's still body on her deathbed seems more than the conventional allegory of vanitas; it also emphasizes the options open to women and points the moral to those who, however innocently, stray. The happy inmate, embodied by that impossible character Esther Summerson (and she is perhaps so insipid and unbelievable because of this), is a romantic projection conveying a familiar mixed message. She is romantic in the sense of being other: her imprisonment ensures male freedom according to the logic the book sets up when the housekeeper, Mrs. Rouncewell, argues that Lady Dedlock's disclosure of her guilty domestic secret will free the housekeeper's favorite son from prison. ${ }^{46}$ And she is also romantic in the sense of being ideal: her characterization keeps the dim sense of oppression neatly masked and sentimentalized in the "obligations of home" (6.113) that she willingly embraces. ${ }^{47}$ Esther is the heart of this novel's romance: its first critics recognized her story as "sadly romantic enough," tacitly acknowledging that the very purpose of romance is to displace sorrow on women. ${ }^{48}$ With her basket of keys, she is also the embodiment of home in Bleak House, a warder who actually locks herself up: she monitors most closely her own emotions so that she can remain happily incarcerated within Bleak House (and that name is also her euphemism for her pending marriage with Jarndyce).

Jarndyce's relation to Esther especially posits a male order that is in control of women's subjection, and, if not free from the prison

${ }^{46} \mathrm{~A}$ woman's guilt does ultimately free George, who then willingly chooses to stay with his mother in Chesney Wold, bringing an end to all his wanderings. George's freedom from prison may be the blind that permits this self-incarceration within the home. The book depicts George restraining himself within a realm foreign to him out of deference to his mother, whose domain it really is-an excess of filial piety that is part of the humor of his character. But the comedy hides a wishthat men aren't really part of the domestic-to cover over a suspicion-that men too are entrapped within the kind of structures the home represents.

${ }^{47}$ The plots of many of Dickens's novels, in fact-consider Estella in Great Expectations, or Bella in Our Mutual Friend - train women for this role, or, as these novels present it, raise them to this ideal.

48Review of Bleak House, in the Athenaeum, excerpted in Dyson, Dickens's "Bleak House," 50. 
itself, then at least able to subject others. Jarndyce's response to his own implication in the Chancery suit has been to organize and administer Bleak House(s), converting the desolation caused by Chancery into what seems a private asylum, recovering Bleak House from its initial (and seemingly essential) similarity to Tom'sAll-Alone (8.146-47). Yet that transformation is maintained only by employing Esther, as housekeeper, to keep it up vigilantly. Esther, as willing servant, custodian of all Bleak House represents, ensures that Jarndyce will be its "generous master" (6.117). Her honorific for him, Guardian, suggests that he needs especially to appear a benignant master over her, one divorced from the kind of brutal exploitation on which mastery depends, one who somehow exerts no oppression. But Jarndyce's guardianship makes Esther's relation to him little different from that of the cottager wives to those they explicitly acknowledge as their masters. "'I'm a-watching for my master,' [Liz tells Esther]. 'If he was to catch me away from home, he'd pretty near murder me.' 'Do you mean your husband?' [Esther asks]. 'Yes, miss, my master'" (8.161-62). Jarndyce is like these masters if only because he wishes, against what would be Esther's will (if she had one), to keep her mistress of Bleak House and become her husband. Jarndyce's mastery, and Esther's pliancy, cannot be better represented than in the way he hands her over to Woodcourt, making clear her identity as chattel-a transaction that serves not just to point his power and beneficence but to propagate the institutions, the Bleak Houses, over which he is master.

Women's enclosure within the home circle also draws off the more general and pervasive constrictions of closure-not just, as Nell demonstrates, because women are sacrificed to closure but, as Esther shows, because they also willingly create it. Esther is "intent upon the perfect working of the whole little orderly system of which [she is] the centre" (37.587). Esther seems to keep in order more than just the home; unlike Nell, whose rambles dissipate and protract the plot of her novel, Esther's steady, homely virtues seem to keep her book tidy. Critics have long recognized that Esther is the focus of both narratives in the book, the peg that holds them together. ${ }^{49}$

Yet Esther's relation to closure is illusory, although to recognize it

499ee, for example, A. E. Dyson, "Bleak House: Esther Better Not Born?" in Dyson, Dickens's "Bleak House," 271. 
as such holds no promise for her of an escape from constraint. The stylistic hallmark of Esther's narration is circumlocution. Esther's confusion and deferrals extend even to the conclusion of her story, which, rather than closing the novel, never fully ends but stops on the threshold of another and-then: "-even supposing -" (67.935). Her voice converts onto a personal and domestic level the nebulousness and aimlessness of the engulfing system of power in which she operates. The endlessness of Esther's narrative echoes the way women are characteristically sacrificed to the perpetual enslavement of the everyday: the monotonous and self-perpetuating drudgery performed by slaves of the home like Guster or the Marchioness also reflects the dynamic by which such an overly elaborate and interminable system extends and prolongs itself.

Desultoriness and circumvention are, once again, restatements of the very logic they seek to elude. Esther's double, Lady Dedlock, for example, seems antithetical both to Esther and to the home she represents. Unlike Bleak House, her home, Chesney Wold, is no home at all- "Fairy-land to visit, but a desert to live in" (2.58). But although-or because-Lady Dedlock's transgression with Hawdon has precluded the possibility of any home life (she confesses to Esther, "I have no home left" " [55.816]), she is introduced gazing longingly at a domestic scene; her transgression is converted into a renewed appreciation of the domestic, a reassertion of its claims.

Lady Dedlock's sexual transgression is figured in terms of wandering; it has placed her on a "dark road": "From day to day, sometimes from hour to hour, I do not see the way before my guilty feet' " (36.565-66). The disclosure of her secret literally takes her out on the street, precipitating the reckless tramp through the countryside that ends in her death. Yet, although Lady Dedlock is compared to that great lady of unquiet pacing, Lady Macbeth (48.706), her reckless tramp only seems to threaten what it actually reasserts, the home and the governing order. Not only has home life been made particularly precious to Esther because of her mother's disregard of it, but Lady Dedlock's return to Hawdon at the end of the book brings together parents and child in the graveyard, reuniting them in an accession to the family so powerful in its symbolic expiation of sexual guilt that it cleanses Esther of the taint of illegitimacy and permits her to enter the family circle; after this 
reunion, the objections of Mrs. Woodcourt or even Guppy to Esther's right to a home magically dissolve.

Lady Dedlock's transgression not only establishes Esther even more firmly within the home circle, it also seems to grant men power over that circle. Her sacrifice to the sanctity of home life identifies the home with power, conflating both in a single, neverending, and indifferent succession to which women, not men, are sacrificed. Tulkinghorn, for example, employs such logic to trap Lady Dedlock: "'As to sparing the girl, of what importance or value is she? Spare! Lady Dedlock, here is a family name compromised. One might have supposed that the course was straight on-over everything, neither to the right nor to the left, regardless of all considerations in the way, sparing nothing, treading everything underfoot'" (48.716). Keeping woman in her proper placeunderfoot-guards patriarchy, shoring up lineal descent and saving the family name; by persistently thrusting women beneath this juggernaut's wheel, the novel also allows patriarchy to identify itself with the headlong course of power, which deflects and coopts even what seems the most random or reactionary motion. Nor is such an attitude merely the sophistry of villains: Bucket, too, claims control of women's supposed errancy when he tells Esther he is keeping her wandering mother "in train" (57.828).

Tulkinghorn's death (like Sir Leicester's incapacitation) suggests not only the tenuousness of the men's claim to such power but also their tenacity in asserting that claim, even to the sacrifice of instrumental members. The novel makes a point of mentioning that Tulkinghorn's death actually ensures Lady Dedlock's own (55.81516). The male order regroups around a figure who dramatizes (the wish) that the member is instrumental: Mr. Bucket, who solves the case and reasserts closure by aid of his hypnotizing forefinger. He does so not just at the expense of women but with their help-not only the help of invaluable Mrs. Bucket (enthralled, the text suggests, as much by that forefinger as Mrs. Quilp is by Quilp's burning cigar) but also of that exemplar of order, Esther (whose narration may be Dickens's fullest representation of the inside of a woman's mind because it shows one so brainwashed by and intent on maintaining the male order).

The need to beat wayward women into line may explain Dickens's 
own obsession with the murder of Nancy, his insistence on ending his public readings with an enactment of that scene. ${ }^{50}$ One consoling myth of the Dickens canon, if not of culture, is that beaten women become docile and disciplined subjects, more ready to follow the lead of their men. As Bucket tells us, "any fool knows that a poor creetur like her, beaten and kicked and scarred and bruised from head to foot, will stand by the husband that ill uses her, through thick and thin" (52.836). But Nancy, who exemplifies the principle of standing by her man, also dispels its consolation. Nancy doesn't quite fit the bill. Although she tries to remain constant to him by omitting his name from her indictment of others, he takes the very mission on which she does this as an attempted escape from his lockup (fittingly, she goes to walk on London Bridge with Rose and Mr. Brownlow).

Upon learning of her supposed inconstancy, Bill will not spare the girl. He goes to murder Nancy, taking the straightforward route Tulkinghorn identifies as the path to domination: "Without one pause, or moment's consideration; without once turning his head to the right or left, or raising his eyes to the sky, or lowering them to the ground, but looking straight before him with savage resolution . . . the robber held on his headlong course." 51 Yet his path is not so straightforward; its goal, Nancy's death, fails to conclude Sykes's journey. After Bill murders her, he is immediately possessed by her ghost. His ability to control the movement to which he has sacrificed her vanishes, and he becomes a victim of it himself: "Soon he was up again, and away, - not far into the country, but back towards London by the high-road-then back again-then over another part of the same ground as he already traversed-then wandering up and down in fields, and lying on ditches' brinks to rest, and starting up to make for some other spot, and do the same, and ramble on again" (OT.48.424). Bill's restlessness is, like that of Dickens's wandering women, a response to power, the only difference being that in his case the agency of that power is more distinctly localized: he is chased by the king's officers, and in his frenzy he conveniently hangs himself, sparing them the trouble. Bill's sacrifice is as necessary as Nancy's for the safe home set up for

50Johnson, Charles Dickens, 2: 1102-14.

${ }^{51}$ Charles Dickens, Oliver Twist, ed. Peter Fairclough (1966), ch. 47, p. 421; all future references (hereafter abbreviated OT) will appear in the text. 
Oliver and Rose at the end of the novel, and although the novel partly accounts for this male sacrifice in terms of class (Bill's violent end substitutes for the better-born Monk's more subdued death), Dickens's treatment of gender shows that class provides another displacement of what is a threat to all men.

Dickens expresses his recognition that men are not free of the power relations they attempt to elude in part through his identification with Nancy, his assumption of her victimization. His obsessive murdering of her was also self-murder: he enacted the scene against the advice of doctors and friends, who told him the excitement on top of his ill health was suicide, as indeed it was. Dickens's figuring of romantic restlessness in terms of walking is particularly revealing not only of his own identification with victimization but also of his desire to elude it. Robert Newsom points to a short piece of Dickens's, "Night Walks," in which Dickens literally becomes a streetwalker (as, in life, he actually was: every reader of Dickens's life recognizes his wayward twenty-mile tramps through London as its hallmark). Streetwalking was, in fact, the impulse at the very heart of Dickens's work: he acknowledged quite explicitly that it was vital to this creative powers. ${ }^{52}$

Dickens's identification with woman shows that he recognizes her portrayal as symptomatic. His representation of woman lays bare the way power inscribes itself; it points ultimately, through the repeated failure of the male strategy to control or differentiate itself from her representation, to the way men, like women, are also inscribed in power. And that identification also exposes the inscription of Dickens's texts within power. Ellen Moers, examining the perceived threat of women's activity to male power in Bleak House, suggests that such fears in the novel have their source in anxiety about writing, in the male uneasiness about the growing power of female writers. ${ }^{53}$ This uneasiness, however much it might owe to social fact, also expresses a recognition that the construction of woman functions just as writing itself works; like the construction of woman, writing cannot offer an escape from the

52See Newsom, Dickens on the Romantic Side of Familiar Things, 107-13; Fred Kaplan, Dickens and Mesmerism: The Hidden Springs of Fiction (1975), 76; and Johnson, Charles Dickens, 1: 518, where Dickens blames his inability to write in Italy on missing his London night walks.

53Moers, "Bleak House: The Agitating Women," 22-24. 
contingencies and restrictions of that unrecognizable set of forces that have come to be called power. Inscribed within those forces, writing necessarily provides one more field in which power operates. (And because that field of forces determined by social and historical facts also determines them-it always inhabits, at any rate, the endeavor to perceive and organize facts, determining the logic of representation by which history becomes available-the question of causality remains moot.)

Yet Dickens's identification with woman also betrays the reassuring power of identification itself and points to the versatility of the dynamic of the other, the way it seems to allow identification while preserving distance. Dickens's own collusion of romance and women exposes the doubleness of the male position, which can concurrently imagine itself as inside and outside of power. In Dickens's most self-revelatory novel, David Copperfield, which chronicles Dickens's own growth as a writer, young David enters into storytelling by putting himself in a woman's place-David's love for Steerforth prompts him to become his Scheherazade. The identification with women and romance, it seems, is meant to further the connections between men. But even such identification is itself consolatory; Scheherazade, although under a threat, is ultimately spared, which may explain why the Arabian Nights was Dickens's favorite romance. The purpose of romance remains: to provide a way to lessen the very constraints it also reveals.

\section{III}

The interplay between the streetwalker and the homebody is restaged in the recent critical debate between deconstruction, on the one hand, with its emphasis on errancy and transgression, and the analytics of power, on the other, with its focus on the totality of control. Within this debate, woman-and her discourse, feminism-are crucial, if often unrecognized, terms. Both schools make use of constructions of women to further their claims and provide romantic consolations for their contradictions, inconsistencies, gaps, or self-indictments. Both schools have also profited from feminist inquiry: deconstruction's concern with the marginal, for example, learns from as well as lends itself to feminist discussions of women's impossible position within an order that cannot recog- 
nize them; similarly, investigations of the private as the microsphere of supposed public domination owes much to feminism's refusal to allow a schism between the public and private.

Recent attention to the wandering of the text (such as by Barthes and Parker) is predominantly deconstructive. Alice Jardine, for example, traces to Derrida's work-to Dissemination and Margins of Philosophy - an emphasis on "the adventures of a certain wandering, without telos or finality, without domination or mastery. In order to pry apart the metaphysical oppositions that have chained us, we must begin to follow the movements of difference-in-motion (physis) before it is chained by truth, syntax, and sign." 54 Derrida's followers have seemed to point to this model of wandering as the means to transgress order and domination, and Derrida's rhetoric has specifically seemed to open up the possibility of such transgression for women-or rather to suggest that the position of woman is by definition transgressive. Although Derrida may claim that there is "no name" for this wandering difference, he also asserts as feminine the unrepresentable, the transgressive and erring, the involuted hymenal boundaries, the maze of invaginations, which prompts him to wish to write "as (a) woman."55

Yet the pervasive idea that deconstruction promises a realm outside the metaphysical assumptions it assails (and that it claims that realm for its own operations) is inaccurate and misleading. As Derrida himself has suggested throughout his work, transgression relies on and calls forth, in an endless cycle, the very law it subverts. ${ }^{56}$ What is problematic to feminism about deconstruction is not that the old order persists (as it must) within deconstruction's own play. What is problematic is where it persists, precisely where readers of deconstruction might least expect to find it, given the

54 Alice A. Jardine, Gynesis: Configurations of Woman and Modernity (1985), 130.

55Derrida's claim that there is "no name" comes from Jacques Derrida, "Différance," in his Margins of Philosophy, trans. Alan Bass (1982), 26. The other claims may be found in Derrida, "La Question du style," Nietzsche aujourd'hui? (1973), 1: 229; quoted by Stephen Heath in "Male Feminism," Men in Feminism, ed. Alice Jardine and Paul Smith (1987), 4.

${ }^{56} \mathrm{See}$, for example, his claim that "it is not a question of junking these concepts [the sign, with its logo- and ethnocentric assuredness], nor do we have the means to do so. . . . Breaks are always, and fatally, reinscribed in an old cloth that must continually, interminably be undone" (Jacques Derrida, Positions, trans. Alan Bass [1981], 24). 
critique of phallogocentrism basic to deconstruction: woman becomes one site on which that approach consistently repeats the gesture of mastery.

Derrida's recourse to woman as metaphor for the unrepresentable and inconsistent still relies on an old essentializing logic, on which the complications of the play of language and its refusal of reference still depend and which they cannot completely subvert (but even partially serve). By relying on the familiar construction of woman as herself inconsistent and incomplete, biologically and sexually lacking, this logic also repeats that construction. Derrida's critique of the supposed need of feminism for some simplistic referential category of woman has led to his skepticism of, if not antagonism to, feminism. ${ }^{57}$ But feminism also must be skeptical and can never simply make assumptions about its relation to deconstruction, even as it borrows from its methods.

At the same time, the current reaction against deconstruction can also make use of women in the consolatory way that Dickens's novels do. Identification with the symptomatic woman acts out the inevitable collapse with the other. That collapse, however, can also be a further strategy to claim power: Lady Dedlock as the wandering mother reveals the maneuver by which that woman of symptoms - the hysteric - allows the text to continue to try to inscribe power as well as be inscribed within it. Dickens brings together his two avatars of romance, recast as wandering hysterics and hearthtending mothers, in a strategy of collapse that betrays how collapse itself is useful.

Madwomen and mothers. When stated baldly this might seem an odd coupling indeed, yet their pairing has been useful for different approaches of feminist literary theory as a way to expose gender ideology. Although such feminisms have attended to women's particularity - the differences between madwomen and mothersthey have also found connections and similarities between them. Perhaps the most familiar example of the association of hysterics and mothers appears in feminist responses to Freud's treatment of

57See Jacques Derrida and Christie V. McDonald, "Choreographies," Diacritics 12 (1982): 66-76, especially 70-76; and James Creech, Peggy Kamuf, and Jane Todd, "Deconstruction in America: An Interview with Jacques Derrida," Critical Exchange 17 (Winter 1985): 1-33. 
Dora. Dora refuses his treatment, some feminists claim, precisely because Freud will not follow up the insight granted him by Dora's first dream - that "the mystery," as he tells her, "turns upon your mother"-because he refuses to understand Dora's unhappy recognition, that (despite the self-interested lies of the men in her world to their mistresses and patients) the only role for women is her effaced and ignored mother's. ${ }^{58}$

Dickens's portrayal of a figure like Lady Dedlock also pairs hysterics and mothers; she is driven by her repressed nature into mad frenzy that ultimately becomes flight-maddened, in fact, because she is a mother. Connections between these two figures are apparent in the terms popularly applied to them as well: "the mother" is the archaic synonym for hysteria; hysterics and mothers are also both "confined," and this confinement has made them especially useful figures for some feminisms, providing a focus through which to examine "women's sequestration or invisibility in patriarchal and phallocentric systems" as the ground and prop of those systerns. ${ }^{59}$ One common form of the connection between the madwoman and the mother is typified by some French feminist readings - the hysteric's insistent bodily presence stands for, refers back to, and is given sense by the horizon of the unrepresentable mother.

Yet these invaluable anatomies of patriarchy may not take their questioning and interpretation far enough; by connecting the hysteric and mother, however implicitly, they also act out the logic of the systems they expose. A more current rephrasing of the association of the hysteric and mother might see in the hysteric's tortured body not subversion but the symptom of her cultural incarceration, might associate the unrepresentability of the matrix generating her

58Freud, "Fragment of an Analysis of a Case of Hysteria," SE, 7: 70. For readings of Dora that foreground the connection between hysterics and mothers, see, for example, Jerre Collins, et al., "Questioning the Unconscious: The Dora Archive," Diacritics 13 (Spring 1983): 37-42, and Sharon Willis, "A Symptomatic Narrative," Diacritics 13 (Spring 1983): 46-6o.

${ }^{59}$ Mary Jacobus, Reading Woman: Essays in Feminist Criticism (1986), 286. Jacobus engages particularly with the strategies of French feminists such as Luce Irigaray or Julia Kristeva. For a similar argument that also draws from Anglo-American objectrelations psychology, see Margaret Homans, Bearing the Word: Language and Female Experience in Nineteenth-Century Women's Writing (1986); and for one that works from Marx, Foucault, and the new historicism, see Eve Kosofsky Sedgwick, Between Men: English Literature and Male Homosocial Desire (1985). 
not so much with an invisibility eluding control as with the omnipresence of a vast system of control that is ineluctable.

But is the hysteric's relation to the mother in even this last, Foucauldian, paradigm of power relations I just paraphrased actually all that different? Foucault too, in The History of Sexuality, couples hysterics and mothers in his critiques of the prevailing sexual system: the mother, he writes, is "the most visible form of . . hysterization." 60 Connecting the mother and the hysteric in this way may allow us to see them as constructions, to see sexuality as simply a strategy through which power deploys itself. But such a connection may also continue a long history in which a proper mastery of these figures has been crucial: Foucault's collapse of the hysteric and mother, for example, supports an argument directed at refuting Freud (and Lacan), in the same way that Freud had redefined the hysteric in his refutation of Charcot. To keep our feminist investigations from unwittingly replaying and supporting such (male) moves for power, we might wish to question the logic we often just assume.

What would happen if we separated these two figures, mothers and hysterics - if only to forestall their inevitable collapse? By doing so, we might be able to determine not just the function of their equation - the ways it serves phallocentrism-but also why these two in particular are equated. Feminist scholarship is already engaged in similar work in many areas; different feminists have examined the ways that Freud, for instance, seems to have anticipated and stymied our attempts to "think back through our mothers" (the project Virginia Woolf sets us); they have shown that Freud's view that woman's essential neurosis can be explained and cured only by the maternal is just another way to appropriate woman to the paternal, to reassert her dependence on man, her inferiority and subordination to him, figured in the equation in which motherhood equals and satisfies penis envy. ${ }^{61}$

${ }^{60}$ Foucault, History of Sexuality, 1: 104. I might say that such a coupling points to the sense of "coupling" that means, according to the Random House Dictionary, "the association of two circuits or systems in such a way that power may be transferred from one to the other."

61For an example of just such an investigation, see Mary Jacobus, "In Parenthesis: Immaculate Conceptions and Feminine Desire," in Body/Politics: Women and the Discourses of Science, ed. Mary Jacobus, Evelyn Fox Keller, and Sally Shuttleworth (1990), 11-28. 
I want to conclude my reading of romance in Dickens by examining what the fusion of madwomen and the mother tells us about the role of gender in the analytics of power and about the role of feminism in current critical debate. The fusion of the hysteric with the mother domesticates power relations simply because it is fusion; contemplating an unlocatable, pervasive field of force that absorbs the subject, and locating and specifying that field as the mother, furthers a fantasy of benign identification, of osmosis and harmony with a nurturing source-furthers, in short, that romantic fantasy of the pre-Oedipal that I discussed in the chapter on George Meredith's fiction. Although this fantasy is imagined as being played out between women, I might argue that it is actually phallocentric - that an analysis that reads the hysteric back to the mother is essentially a male fantasy, one that acts out what Alice Jardine calls the logic of "male paranoia." Paranoia, as Freud's reading of Schreber demonstrates, involves not just an identification with women; its desire for the breakdown of boundaries is in service of an imagined merging of the subject with the forces authorizing and subordinating it, a fantasy of union with "that being who has no boundaries" whom Schreber called God but, Jardine notes, has often been called Mother. ${ }^{62}$ Paranoia seems to allow a more privileged relation to systems of power than hysteria. The paranoid's privileged position becomes apparent in Freud's tacit-and wishful-hierarchy: (female) hysterics are bodies to be inscribed and analyzed within systems; (male) paranoids are involved in the very production of those systems. Such privileging is not surprising, for in their own dependence on fantasies of totality, whether called God, Mother, or even psychoanalysis, Freud and Schreber (as Freud recognized) share a paranoid logic. ${ }^{63}$

62Jardine, Gynesis, 98; see her discussion, 98-102.

63Freud writes: "It remains for the future to decide whether there is more delusion in my theory than I should like to admit, or whether there is more truth in Schreber's delusion than other people are as yet prepared to believe" ("PsychoAnalytic Notes on an Autobiographical Account of a Case of Paranoia," SE, 12: 79). Freud also makes the connection between paranoids and analysts in "Constructions in Analysis." He writes: "The delusions of patients appear to me to be the equivalents of the constructions which we build up in the course of an analytic treatment" (SE, 23: 268).

For a reading of women's relation to paranoia and theory which discusses these and other connections, see Naomi Schor, "Female Paranoia: The Case for Feminist Psychoanalytic Criticism," in her Breaking the Chain: Women, Theory, and French Realist 
It has been suggested recently that paranoia is the subject's most salutary response to our implication within power relations. ${ }^{64} \mathrm{But}$ paranoia can be consoling as well as salutary, providing a structure that identifies those defined as male subjects with ultimate authority -an identification that at the same time seems to circumvent the oppressive logic that has previously made identifications with power appear as the products of a clear-cut desire to dominate. Foucault-inspired criticism has been particularly useful in pointing out how the supposed exemption of the subject from systems of control actually shores those systems up. But simply recognizing and making explicit that we all-men and women both-are inscribed within power doesn't settle anything and can lead to an embracing rather than a denial of power, an opposite but just as dangerous response. The different histories we construct as feminists tell us that (that group we call) men has always tried to embrace power by exercising it over women and that men's domination of women is one way that men can console themselves for, and seem to deny, their own subordination to authority. One part of the feminist task right now might be to point out that oppression has not disappeared simply because we have ways of rethinking and complicating it-oppression still could be part of the structure of that thought; we might counter the claim that no one owns power with the observation that some wield it nonetheless.

One way to continue questioning oppression might be to question the collapse between the hysteric and the mother-ultimately to question the strategy of collapse itself, especially insofar as it involves an ironing out of all differences-including gender differences, however various critics might locate those. As different feminists have begun to point out, current descriptions of power

Fiction (1985), 149-62. Keep in mind that for Freud hysteria and paranoia could be related in women through the figure of the mother. In "Female Sexuality," he writes that the first attachment to the mother, the pre-Oedipal phase, "is especially intimately related to the aetiology of hysteria, which is not surprising when we reflect that both the phase and the neurosis are characteristically feminine, and further, that in this dependence on the mother we have the germ of later paranoia in women" (SE, 21: 227).

${ }^{64}$ By D. A. Miller, The Novel and the Police, 70. See also his reply to Dominick LaCapra's response to that argument: Miller, "Under Capricorn," Representations 6 (Spring 1984): 129. See too Dana Polan, Power and Paranoia: History, Narrative, and the American Cinema: 1940-50 (1986). 
relations seem to break down the gender distinctions feminism relies on, replacing patriarchy, phallogocentrism, or the symbolic order with an undifferentiated system-one not explained by gender, but explaining and dispensing with it, as merely one tactic of control among many. ${ }^{65} \mathrm{I}$ might question whether this is prescription as well as description, itself just one more restatement of what we represent as male logic, and one that in supposedly eliminating gender actually only effectively eliminates woman, installing instead the very homosocial male grid it analyzes, authorizing the male position even as it recounts the control and violence it sees exercised on those occupying it. I shall investigate the problems of this current critical paradigm of power relations for recent feminism-examine the way feminism has been if not appropriated then reinflected, as Nancy Miller or, following her lead, some feminist respondents in the anthology Men in Feminism might call it. The differences between recent feminist literary criticism and other critical discourses are difficult, if not impossible, to hold apart because they lie in nuances of tone and style: whether or not those differences are ultimately outside anyone's range, and whether or not anyone can isolate them, my attempt to do so might at least help note the way that current attempts to de-emphasize gender distinctions can mean an emphasis added that reasserts the male register. ${ }^{66}$

In the nineteenth-century novel, two restless and hysterical figures especially capture the imagination, providing, as blank enigmas that continue to prompt interpretation, the very screens on which we as critics project our understandings of hysteria. We could, in fact, argue that one figure is the interpretation of the other, for Dickens's Miss Havisham followed close upon Collins's own woman in white, the appearance of Anne Catherick in Collins's

\footnotetext{
${ }^{65}$ See, for example, Naomi Schor, "Dreaming Dissymmetry: Barthes, Foucault, and Sexual Difference," in Men in Feminism, 98-110.

66For her discussion of these important inflections, see Nancy K. Miller, "Emphasis Added: Plots and Plausibilities in Women's Fiction," PMLA 96 (January 1981): 3648. The question of enunciation and tone is implicit in many of the essays in Men in Feminism; for representative selections, see Alice Jardine on "syntax or intonation" (56) in "Men in Feminism: Odor di Uomo or Compagnons de Route?" in Men in Feminism, 54-61, and Meaghan Morris on innuendo and punning in "in any event . . .," in Men in Feminism, 173-81.
} 
novel embodying for Dickens one of the most memorable scenes in literature and immediately prompting his reworking of it. ${ }^{67}$ Anne Catherick of The Woman in White and Miss Havisham of Great Expectations stand out as romantic figures; as I have shown, Dickens's early critics found Miss Havisham especially romantic, and Count Fosco himself, in The Woman in White, recommends the plot he has built up around Anne to "the rising romance writers of England."68 And Anne Catherick and Miss Havisham embody too Breuer's definition of hysteria as "suffer[ing] mainly from reminiscences"69_for their bodily agitation (Anne's "nervous, uncertain lips" [WIW.48] and Miss Havisham's "impatient fingers" [GE.12.126]) stems from their apparently unspeakable memories. Unlike Freud's and Breuer's hysterics, however, their cases seem distinguished not by how much they are forced to forget but by just how much they remember: Anne, although slow to gain an impression, is tenacious in recalling it (WIW.121), a relation to memory perfected in Miss Havisham, whose whole existence enshrines reminiscences of ill treatment she cannot eradicate. The transparent relationship of symptom to memory seems obviously to call into question what Foucault terms "the repressive hypothesis" of psychoanalysis. ${ }^{70}$ Yet in order to maintain that hypothesis and the privileges it allows, these books seem merely to beckon readers elsewhere for our archeologies, mapping out on the body of the text a depth psychology that points to a textual unconscious, takes readers behind the stories of the hysterics to an external origin-the story of the mother, which gives sense to the text as a whole.

That these are women in white already suggests as much. ${ }^{71}$ Their inappropriate white dress-others in Anne's novel find her

67Martin Meisel, "Miss Havisham Brought to Book," PMLA 81 (June 1966): 281.

${ }^{68}$ Wilkie Collins, The Woman in White, ed. Julian Symons (1985), 48. All future references to this book (hereafter abbreviated WIW) will appear in the text.

69Josef Breuer and Sigmund Freud, "On the Psychical Mechanism of Hysterical Phenomena: Preliminary Communication," SE, 2: 7; Anne's identity as a hysteric is emphasized by the original of her story, the hapless Madame de Douhault, who was immured in the Salpêtrière, which was later to become the most famous site of hysterics; see Clyde K. Hyder, "Wilkie Collins and The Woman in White," PMLA 54 (1939): 299.

70Foucault, History of Sexuality, 1: 10.

${ }^{71}$ For an extended discussion of literary figurations suggested by women in white, see Sandra M. Gilbert and Susan Gubar, The Madwoman in the Attic: The Woman Writer and the Nineteenth-Century Literary Imagination (1979), 613-21. 
white clothes "particular" (WIW.117), as clearly Miss Havisham's bridal dress also is-itself marks their insufficiency and gestures to something beyond them; Miss Havisham's story relies on the reader's assumption that what one critic emphasizes as "faded virgin white" is unnatural, that she has become hysterically immobilized in what would have been the proper development from bride to mother. ${ }^{72}$ Miss Havisham's unnatural mothering of Estella (Dickens's revision of Collins makes his figure more economically both hysteric and mother, emphasizing the strategic collapse between them) only reinforces her inadequate progression into maternity and sends the reader, like Pip, looking elsewhere. The mystery of Great Expectations turns out to be not this mysterious woman's: Herbert recounts her history quite easily halfway through the book. Instead, Pip follows Miss Havisham's story back through Magwitch and Estella to arrive ultimately at Estella's real mother, Molly, who connects all the threads of the novel. Likewise, Walter Hartright makes no headway in restoring Laura's identity and fortune, and the plot of his novel remains tangled, as long as he suspects that "the way to the Secret lay through the mystery, hitherto impenetrable to all of us, of the woman in white" (WIW.475). Only when he realizes that Anne knows nothing, that it is her mother, Mrs. Catherick, who alone is "in possession of the Secret" (WIW.492), can his search and the novel begin to wind up.

The mother too is inherently associated with romance in these works. Nell must be sacrificed, for instance, not just because she is wandering, but because she is houseless and motherless: she lacks the guidance of that pattern of control who would take her within this other circle of romance and keep her in order. Similarly, when the character in Pickwick notes that "there is romance enough at home" (foreshadowing that exemplary instance of the woman imprisoned by the home, which ought to be enough for her, Miss Havisham in Satis House), his particular romance tells the story of a suffering mother.

That the mother, in a sense, controls and shapes these novels is in keeping with cultural and linguistic constructions of her. The connections of the mother with creation go without saying, of

72Meisel, "Miss Havisham"; the phrase I quote appears on 279, but see his further discussion, 282-85. 
course, but they can be easily reworked in such a way as to connect them with current theories of totalizing power, of the structures of discipline creating the very subjects that make them up. Feminist exponents of matriarchy might argue, for instance, that the mother's confinement during delivery is meant to deny what they see as a sign of her predominant creative and controlling power: her power quite literally to give birth, to produce subjects. Such views are also similar to those of Karen Horney and Melanie Klein in their debate with Freud about the construction of femininity. They not only insist on a dread that prompts men to disparage women in order to allay their own envy and fears, but they locate that dread as dread of the mother. ${ }^{73}$ Recent feminist object-relations psychology works from this view, namely that the mother has been reviled and occluded because of the power she possesses as well as the subject's difficulty in separating from her; they argue specifically that the mother's role as caregiver equates her with the structures of discipline that define the subject, which therefore rebels against them. The power they accord her position is so all-encompassing that writers such as Dorothy Dinnerstein argue that its problems can lead to total annihilation, to nuclear apocalypse. ${ }^{74}$

(Let me digress a moment to say that I am neither suggesting that these assumptions represent fact-their pretension to fact, to an essential identify of the mother as well as of gender, actually risks collapsing them with the very phallocentric positions they are attempting to refute-nor suggesting that we should adopt them. Rather, I review them only to suggest some of the ways in which the mother gets linked to fantasies of power and to consolations within those fantasies-a dynamic these views of the mother expose but also act out too unself-consciously themselves. Whether [what we call] male subjects or female theorists make the equation, the mother comes to stand for a total and totalizing system. But even if they don't take their observations far enough, I think these theorists are useful in indicating the way such a connection serves the male order-feminist object relations, for example, implies that

\footnotetext{
73See Karen Horney, "The Dread of Woman," International Journal of Psychoanalysis 13 (1932): 348-60; and Melanie Klein, "Early Stages of the Oedipal Conflict," International Journal of Psychoanalysis 9 (1928): 167-80.

${ }^{74}$ Dorothy Dinnerstein, The Mermaid and the Minotaur: Sexual Arrangements and Human Malaise (1976).
} 
women are made primary caretakers to provide patriarchy with a convenient scapegoat for its ills.)

The construction of the mother who governs Great Expectations appears to present both the mother's totalizing power and the subject's difficulty in separating from her: Pip (in a binding oscillation of incorporation and "repulsion" that seems to allow him no comfortable position) tells us that the "government" (GE.7.79) of even his foster mother, Mrs. Joe, is all-embracing, monitoring his (hopes of self-) creation and preventing his deliverance, or delivery, as an autonomous subject- "I had no hope of deliverance through my all-powerful sister, who repulsed me at every turn" (GE.2.46). In a more extreme example that is simply the logical extension of Pip's case, Jaggers shows off the great strength of Molly, who is believed by everyone to have destroyed her child; she embodies the total control of the subject, its creation and destruction. Every mother in this book is, if not so obviously omnipotent, similarly bad (those I haven't already mentioned include Herbert's and Startop's mothers, who seem to figure in the book just to make this point), and Dickens's criticism of them all turns to some degree on their abuse of power, the ways they ignore (Mrs. Pocket) or overdo (Mrs. Startop) their duty. Dickens's criticism implies, however, a tacit standard of motherhood, one closer to the mother that spoils than the mother that neglects-an implied ideal of an all-giving mother who devotes perfect care to the subject she produces, not-as in Startop's casespoiling him by identifying him with herself, but by giving up all claim to self and to power, existing only as a reflection of his glory. ${ }^{75}$ In The Woman in White, Walter (whom Mr. Gilmore notes takes "the romanticview" of things [WIW.142]) approvingly calls this quality of self-abnegation "that sublime self-forgetfulness of women, which yields so much and asks so little, turn[ing] all her thoughts from herself to me" (WIW.565). And it is important to remember that Pip's real mother - "Also Georgiana" - in dying may not so much have abandoned him as left him free, or that Molly too has actually given up all control of Estella and become herself a kind of slave, immured by Jaggers. "Natural" mothers, then, seem to underwrite this standard, forgetting themselves so much that they all but disappear. The

${ }^{75}$ Remember that Startop, the mama's boy, looks exactly like his mother, whom he adores (GE.25.226). 
continued specter of these mothers (one of the first questions Magwitch asks Pip is, "'Where's your mother?'" [GE.1.37], implying how determinant of "the identity of things" [GE.1.35] and of Pip her very absence is, just as Molly remains the crucial, though shadowy, key to the plot) suggests, however, that the novel worries that the threat they represent within it persists beyond its wishful construction of their self-abnegation.

The standard of self-effacing motherhood may be impossible, available only in death, but that doesn't forestall the punishment of those who fail to achieve it. The most obvious and sobering case is the smash-up of Mrs. Joe. Foster mothers in fact seem scapegoats who abuse their power precisely in order to be humbled for it (and, at the same time, deflect that attack from what may be the taboobecause total-power represented by the "real" mother). Pip's double Orlick-who calls Mrs. Joe "Mother Gargery" (GE.15.142) crushes her precisely for her attempt to govern him. His brutal overpowering of her reverses with a vengeance the power relations previously existing between Mrs. Joe and Pip. As Dickens makes quite clear, Pip's observation that, after her attack, his sister "showed every possible desire to conciliate [Orlick], and there was an air of humble propitiation in all she did, such as I have seen pervade the bearing of a child towards a hard master" (GE.16.151) puts her in the place of the child Pip once was, and makes him master.

Just as the foster mother is a ploy that denies while preserving the relation between the subject and the mother, the collapse of the hysteric with the mother also seems to promise the hero's freedom, in a way that doesn't compromise him, doesn't make him appear openly resistant to power. By pointing to the mother, confined hysterics such as Anne Catherick and Miss Havisham imply the way subjects are contained within a controlling system. Figuring that system as the mother, however, makes it tolerable, and more tolerable for the hero than the hysteric. Anne Catherick tells Walter, "I don't get on well with [my mother]. We are a trouble and a fear to each other'" (WIW.123). Yet Walter gets on with Mrs. Catherick very well: just as Walter is his own mother's favored son, he becomes a favorite with Mrs. Catherick too. Ultimately, she offers him the story she never gives Anne and suggests she would offer him herself, if he would have her (WIW.548). 
Moreover, the hysteric supplies the hero with an acceptable route back to the mother, because her collapse with the mother allows an identification that preserves the possibility of differentiation. What distinguishes the hysteric is her refusal actually to become the mother, her insistence on separating herself from the very horizon that gives her meaning. Hysterical pregnancies, such as Anna O's, are important because they are false; that falseness defines them as hysterical. Freud, however, does not use such a subtle distinction to separate the hysteric and the mother. Rather, it is held up as the very benchmark of the hysteric's illness; although Freud largely ignores Dora's mother, he repeatedly tasks Dora with what he sees as her neurotic refusal to assume her mother's role, to allay her penis envy, to satisfy with Herr $\mathrm{K}$. or the young engineer her natural but repressed desire to provide the father with a child. Yet the very distance that is neurotic for the hysteric is not so for the hero. The destiny of his anatomy supposedly makes such differentiation normal for him; he is not meant to become the mother. Paranoid rather than hysteric, when merging with the mother (perhaps) he can protect his boundaries by dissolving hers-or so this fantasy runs.

The utility of these hysterics, particularly as women in white, is that the heroes need not simply identify with them, need not risk becoming them by taking over their place; instead, they can assume control of them, make use of them, inscribe their own (wishful) stories on the white blanks offered by these women. The very construction of the hysteric, like that of the mother, effaces itself, makes what it represents seem natural and true, rather than an arbitrary or self-interested fantasy. Dora's description of Frau K's "adorable white body" locates this whiteness anatomically, collapsing sexuality and textuality, and suggests the way in which the hysteric's construction in terms of her bodily symptoms permits the illusion of insight, seems to demand the supposedly natural male response to women, the desire to "penetrate" them-Walter's term, as I quoted previously. What men write on the blank tablet of the hysteric comes to seem the hidden truth revealed, brought to light by analysis. And as Dickens makes clear in Great Expectations, this wishful "truth" is meant to be the hero/analyst's preference and promotion by, even his control over, power. Recorded on this blank is the male subject's humble propitiation by the matrices of power: a broken Miss Havisham, on her knees to Pip, begs him to 
inscribe on her "yellow set of ivory tablets" his forgiveness of her (GE.49.409-10), and, in the end, her hysteria is reduced to her mechanical repetitions of that plea and her self-accusation of bad mothering. ${ }^{76}$

In his excellent analysis of The Woman in White, D. A. Miller reveals the ploys of this false monolith of sexual construction, which assumes that men only desire to penetrate and desire to penetrate only women. In doing so, he outlines the connection in that book, although without explicitly unraveling it, between hysteria and paranoia. In his discussion of the way the hysteric provides "the conduit of power transactions between men" he turns to Lady Audley's Secret, considering it as a coda to Collins's novel, a more explicit dramatization of the way hysteria is a function of social power. ${ }^{77}$ Miller subtly argues here what feminists such as Catherine Clément have already suggested: that the hysteric does not figure women's subversive resistance to her role but actually emblematizes that role itself and legitimates woman's confinement. ${ }^{78}$ What is important to Miller's argument is the way the confined woman is the type for all subjects within power relations-a subject and an agent of power as well. Moreover, Miller suggests that confining the woman, whether in the lunatic asylum or the asylum of family and home, facilitates a process of selfdiscipline aimed ultimately not at the control of women but at defining the power relations between men. Yet, no matter how subtle, the analysis of women as tokens in a privileged relation between men risks merely repeating that structure, unless we make explicit the different inflections-those of culture, text, and critic-that are involved. To point out what this structure tells us about the subject's attitude to power, rather than just his inscription in it, I turn to another wildly popular sensation novel, Mrs.

\footnotetext{
${ }^{76} \mathrm{Her}$ plea for forgiveness once again reverses old power relations and puts Pip in the place of the mother and, even more, of ultimate authority, for Miss Havisham begs him "with her folded hands raised to me in the manner in which, when her poor heart was young and fresh and whole, they must often have been raised to heaven from her mother's side" (GE.49.410).

77D. A. Miller, The Novel and the Police, 169-72 (this chapter is entitled "Cage aux folles: Sensation and Gender in Wilkie Collins's The Woman in White"); the phrase I quote appears on 171 .

78Hélène Cixous and Catherine Clément, The Newly Born Woman, trans. Betsy Wing (1986), 155.
} 
Henry Wood's East Lynne. For East Lynne explicitly refers the hysteric, as it refers all else, back to the mother, exposing in the process the fantasies of power involved in that collapse.

East Lynne is the tale of a fallen mother, the beautiful Lady Isabel, who, through the pressure of sensational circumstances and misunderstandings (the novel acknowledges repeatedly that its events seem romantic), runs off from her husband and children, only to repent (too late) and secretly return, disguised, to watch over them. ${ }^{79}$ Abandoned to debt and dependence on the death of her profligate father, the young Isabel meets her uneasy situation by falling first into hysteria: her precipitous marriage to Mr. Carlyle, a man she only admires, her later tortured and irrational jealousy of Barbara, whom she believes to be a rival for his affections, are just some of the effects of an ill-fated nervous susceptibility, accompanied always by hysterical tears. ${ }^{80}$ Yet this novel makes clear that Isabel is not a special case; hysteria is natural to women (the other women in the novel also cry hysterically throughout it) — natural, it seems, because it is a direct function of woman's most natural role, her maternity: in this novel, women's nervous afflictions appear to come from their motherhood. Isabel has inherited her nervous oversensitivity from her own mother (whose similar impassioned nervousness prompted her to elope with Isabel's father and then waste away repenting the deed); another important mother in this book, Mrs. Hare, has become an hysterical invalid explicitly because she is a mother, separated from her only son.

The frustration of maternity is not what prompts hysteria in this book, however; the very insistence on the collapse between hysteria and maternity itself is the cause. The text does seem at times to try to normalize and naturalize the mother, to locate an unproblematic development into motherhood as what might resolve hysteria and determine normality for women. Isabel's separation

\footnotetext{
${ }^{79}$ Mrs. Henry Wood, East Lynne, ed. Sally Mitchell (1984); for references to romance, see, for example, pt. 1 , ch. 10, p. 80 , and ch. 11 , p. 90; pt. 3 , ch. 6, p. 378 , and ch. 10, p. 417. All future references to this book (hereafter abbreviated $E L$ ) will appear in the text.

80The examples of Isabel's hysteria are extensive; for places where the text particularly uses that term, see East Lynne, 1.10.78; 1.12.102; 2.12.258; 3.2.337; 3.4.362; and 3.13 .437 .
} 
from her children becomes the site, if not the source, of her illness: "But now, about the state of her mind? I do not know how to describe the vain yearnings, the inward fever, the restless longing for what might not be. Longing for what? For her children. Let a mother . . . be separated for a while from her little children: let her answer how she yearns for them" (EL.3.1.327). ${ }^{81}$ Such separation in Isabel's case appears especially destructive because it is cast as unnatural: "A brute animal deaf and dumb clings to its offspring: but she abandoned hers" (3.1.332). Yet the text also carefully shows that Isabel's abandonment of her children doesn't cause her hysterical symptoms, just exacerbates them. Upon returning to her children, Isabel learns that hysteria can also be a function of being too much with them, not just in her own case, but in the case of any mother who devotes herself to them; Barbara (who has, just as Isabel dreaded, taken her place and become Mr. Carlyle's second wife) lectures her that such solicitude will, ultimately, "[jar] on her unstrung nerves" (3.2.341). By suggesting that the collapse between hysteria and maternity is vexed, East Lynne goes beyond simply outlining that motherhood determines and explains hysteria; it also analyzes and critiques that collapse.

The very exaggeration of Isabel's construction is what exposes the dangers to women that lie in the assumption of a connection between these two states: as an extreme case, she merely exemplifies the extension of what seems a natural logic. Isabel's anxious maternity - her miserable return after her flight, maimed and disfigured, to become the governess in her own family, to minister unrecognized to the husband and children she has abandonednot only makes explicit the way a mother is a servant in her family, but the exquisite agony of Isabel's servility, as she finds she is forgotten or reviled and watches her husband love another and her children die, makes East Lynne the premier example of humble propitiation by the mother, of what Julia Kristeva might call her ultimate abjection. ${ }^{82}$ Isabel's deathbed confession, her assumption

\footnotetext{
${ }^{81} \mathrm{Mrs}$. Hare's yearning for her lost son-separated from her by his fault, not her own-in the opening pages of the book sets up from the beginning the connection of hysteria and maternity: " ‘Oh, my boy! my boy!' she wailed: 'my boy! my unhappy boy! Mr. Hare wonders at my ill-health . . . but there lies the source of all my misery, mental and bodily" (EL.1.3.22).

82Julia Kristeva, Powers of Horror: An Essay on Abjection, trans. Leon S. Roudiez (1982).
} 
of blame for all her pain, resolves at novel's end her wild extremes, stops her swing from the mother who neglects to the mother who spoils, and secures her into eternity as the mother who conciliates. That resolution confirms and exposes the assumptions behind the model she has only been thought to violate. For East Lynne makes clear that the bad mother, nervously pleading for forgiveness, does not merely gesture toward some ideal standard of motherhood; she is that ideal. The complete maternal self-forgetfulness the other novels laud is shown here to be Isabel's masochism.

Isabel's abjection directly preserves the social order: her humble return attests to the rightness of society's constructions of maternity, of the naturalness of maternal sacrifice. Isabel and her rival, Barbara, agree in this: that a mother's sacrifices must lead to her children's training, their indoctrination into the laws and morals of society $(3.1 .327 ; 3.2 .341)$. Isabel returns to her children precisely to resume their training, feeling more than ever through her transgression of it the rightness of the social order that punishes her. Yet this novel illustrates, even while repeating it, that the mother is in question because she seems a threat, constructed as a symbol for as well as an agent of this order. All the book's insistence on the mother's selflessness actually screens an apotropaic response to the subject's engulfment by that diffuse and exhaustive system: Barbara brings up how easy it is for a mother literally to smother her children, and how often, her husband has told her, mothers do so on purpose-the incidence of such infanticide is on the rise (3.21.500). Isabel seems to ease, if not undo, the threat of such suffocation for that very husband bothered enough to mention it in the first place: her abasement of herself to him-for he, not the children, is really the reason she returns and humiliates herself ${ }^{83}$ makes him the one who engulfs her attention, keeps him from being engulfed by it.

This sensation novel, submitting to its generic requirements, of necessity offers a moral, which seems to be that "people cannot act with unnatural harshness towards a child, and then discover they have been in the wrong, with impunity" (3.18.469). This statement

\footnotetext{
83Barbara agrees with Isabel in this too: "I should never give up my husband for my baby," she tells her (EL.3.2.343). Dickens also associates this taking care of the father with romance, for when Caddy begs her (bad) mother to take care of Mr. Jelleby after Caddy's marriage, that mother laughs and calls her a "romantic child" (BH.30.480).
} 
refers not to Isabel, however, but to the petty domestic tyrant, Justice Hare, whose banishment of his son has kept him from his mother; upon reunion of mother and child, the father falls into imbecility and powerlessness-he "would never again be the man he had been" (3.18.469) - he literally himself becomes "a little child" (3.22.509). Such justice within the novel may not be the result of the kind of feminist subversiveness Elaine Showalter has argued inheres in sensationalism, for it might be that the father's fate reflects not so much feminist retribution as Oedipal inevitability, and that he is punished for mistreating his son, not his wife. ${ }^{84}$ His regression simply reverses Oedipal roles without upsetting Oedipal structure. It allows his son to become "master" (3.22.510) while at the same time shifting himself to the other privileged position, that of the child, one not that much different anyway in the logic of collapse that underwrites this system. At the same time, by purging a tyrant who explicitly appears unreasonable, the novel strategically seems to satisfy a rebellious imperative and hence allows a much more reasonable (and more dangerous?) tyrant to continue to operate-the reasonable Mr. Carlyle, whose expectations of having his most trifling opinion or desire attended to differ only speciously in emphasis and tone from the infantile demands of the Justice before his supposed comeuppance. ${ }^{85}$ The moral, then, does ultimately redound on Lady Isabel, who remains in the background organizing Carlyle's story just as Mrs. Hare remains a focus with which the struggle between father and son cannot completely dispense. That women are somehow necessary at all keeps them a threat, so that Isabel's repentance about her treatment of Carlyle is required to console the male subject (and

\footnotetext{
${ }^{84}$ Elaine Showalter, A Literature of Their Own: British Women Novelists from Brontë to Lessing (1977), 153-81.

${ }^{85}$ Although these differences of emphasis and tone are meant to be important, Wood cannot maintain them; Carlyle is her experiment in constructing the perfect man, pieced together by changing the emphasis on old literary clichés of gendershe makes him authoritative, say, rather than overbearing, domestic without being uxorious. Yet, like similar experiments (Mr. Knightly, for instance, or Rochester, or Adam Bede, or the inevitable Harlequin romance hero), this one fails because, given the logic of collapse in which this novel is entrapped, the nuances between Carlyle and Hare (lover and father) are not ones it can adequately theorize or maintain; its attempts, however, to imagine a man that might somehow be different, even though they fail, still point out the need to do so. The attempt to transform what may be an inevitable patriarchal grammar through new inflections reveals the oppressiveness of its categories even while failing to transform them.
} 
such consolation, this novel suggests, as Dickens's novels do, remains one of "romantic sentiment" [3.4.361]). Her lack of impunity convinces him of his own.

From its opening, centering on Isabel's ailing father, Lord Mount Severn, the novel sets up the impulse that prompts its trajectory, the problem it must isolate if not solve: the possibility of male powerlessness. The dead patriarch's heir, furious that provision for his daughter should have been considered by the earl as "out of his power" (1.11.84), may be indicting existing gender arrangements that allow the neglect of daughters; he is also outraged, however, by any diminishment of patriarchal power. Men retain their precarious power in this novel by taking it away from women, especially the women who represent it, their mothers: as Lord Vane tells Isabel, "'as to my mother-oh well, she can't expect to be master and mistress too' " (3.7.388); his growing up into an attractive figure is directly a function of his doing "battle with [her]" (3.21.502). The unflattering portraits of mothers who exercise power and therefore must be broken-Lord Vane's evil mother, as well as Carlyle's unreasonable sister, that stock comic type of old maid, his foster mother, Cornelia-reflect the way this novel must necessarily function within the system it also exposes. But the register in which it shouts out its logic forces us to attend to it.

What the exaggeration of this novel makes evident is the consoling strategy underlying the construction of madwomen and mothers. The collapse between these extremes, and between woman's omnipotence and servility, reveals and allows a management of anxiety, a negotiation of power. Our very forms of representation, this novel demonstrates, attempt to order existence in a way that will establish for the male subject a comfortable relation to what controls him. Like Miss Havisham's beseechment of Pip, Isabel's plea for Mr. Carlyle's forgiveness as she lies on her deathbed at the end of the novel attempts to clinch that relation-the system of control, through her as its representative, begs his pardon for its existence. Although he cannot ignore or escape it (Isabel turns up where he least expects her), the system offers him through her this consolation: it directly reflects his desires (she runs away because he loves Barbara) and is always there to minister to his needs. ${ }^{86}$

${ }^{86}$ This system continues after Isabel's death, when Barbara finally can completely assume her place. The novel ends with Mr. Carlyle admonishing Barbara "to strive 
Such consolations for the hero/analyst involve the critic as well. Miller's article on The Woman in White, for example, although it presents itself through its subtitle as gender criticism not feminism, nonetheless owes much to feminist criticism, and Miller explicitly acknowledges the work of Gilbert and Gubar and Eve Sedgwick. ${ }^{87}$ Yet the use of feminism by critics who specify themselves as somehow outside it too remains, as the essays throughout Men in Feminism suggest, "both gratifying and unsettling." 88 Although I admire Miller's insights about gender, I might also want to question how they apply to essays like his own, which can themselves, through their very use of feminism, continue what he himself recognizes as the dynamic in which woman is a conduit of power between men.

Miller's reading of The Woman in White, for example, continues a debate with previous criticism, a tacit critique of one kind of deconstruction-a go-round, which in his exchange with Dominick LaCapra, he has personified as two men dancing; he asks specifically about the problems of difference and mastery between their

always to be doing right, unselfishly, under God" (EL.3.24.525). And although that unselfishness seems to mean that Barbara must learn to love and care for Carlyle's children "as if they were [her] own," she tells him reassuringly that she will do so because "'my earnest wish is to please you'" (EL.3.24.525, 524).

${ }^{87}$ The problems of Miller's engagement in a feminist debate point out the trickiness of nuance that makes the relation of "gender" critics to "feminist" critics, "male" critics to "female" critics, those writing under the male signature to those writing under the female signature (and the use of his initials nicely problematizes such signatures in Miller's case anyway, pointing up how these categories are never firmly established) so difficult to read. For isn't having "them" read and cite "us" precisely what feminist critics want, as implied by the lists of suggestions those writing for feminism have repeatedly offered (see, for example, Sandra M. Gilbert's list and discussion of "us" and "them," in "What Do Feminist Critics Want? A Postcard from the Volcano," in The New Feminist Criticism: Essays on Women, Literature, and Theory, ed. Elaine Showalter [1985], 30-31. See also Alice Jardine's list in "Men in Feminism," 60-61). The problems of how to discuss the differences and relations between feminism and criticism that designates itself as somehow also other, and how to note differences between them without inflecting them merely as the too simple distinction between "them" and "us" (a strained register we ultimately all close our ears to anyway), are precisely what is at issue in this chapter, precisely what it is impossible for it to achieve.

${ }^{88}$ This phrase appears in the standard essay on this topic, Elaine Showalter's "Critical Cross-Dressing: Male Feminists and the Woman of the Year," in Men in Feminism, 117. For an instructive discussion of the homophobic structure that this essay uses but ignores, see Craig Owens, "Outlaws: Gay Men in Feminism," in Men in Feminism, 219-32. 
kinds of criticism, "if it is ever clear, when two men dance, who leads." 89 The complexity of Miller's prose signals that he is well aware of the misogyny (as well as the homophobia) that could be implicit in the exclusion of women that his figure charts; the role of women's exclusion in the homosocial is, after all, part of the argument of "Cage aux folles." His knowing and ironic tone throughout this essay and his other recent work implies that his statement here, in part, ventriloquizes the misogyny and homophobia of traditional positions-held, it implies, by someone like LaCapraand suggests too not just the exclusion of women but also Miller's own willingness (as opposed to LaCapra's) scandalously to play up an identification with them. Yet this is precisely one of the tonal maneuvers that feminism might question because it allows a duplicity that also preserves misogyny. Such duplicity is inescapable; as Christie McDonald has suggested, "in the economy of a movement of writing that is always elusive, one can never decide properly whether the particular term implies complicity with or a break from existent ideology" (and the inescapability becomes increasingly problematic when we complicate the very notion and possibility of "break"). ${ }^{90}$ Yet Miller's refusal to unpack his own language, his silence here about the notorious doubleness of irony (which he himself clearly recognizes in others, as when he refers elsewhere to "ironic reservations that only refine the ambiguity"91), emphasizes that his language does not simply perform but also shares the attitudes it may simultaneously be critiquing. This playful statement about men dancing, for example, dances around but also relies on the assumption that issues of dominance are less complicated or already settled between men and women-men always lead.

In casting its own delicate tonal maneuvers in terms of the dance, Miller's article joins a long tradition that considers implicitly or explicitly the relation of women and their discourse to current critical debate. Although the metaphor of the dance is interesting for a variety of reasons-in the way it domesticates, perhaps in order to trivialize, women's role, in the way it inserts the category of the body into questions of articulation-for the purposes of this

${ }^{89}$ D. A. Miller, "Under Capricorn," 124.

90Derrida and McDonald, "Choreographies," 71.

91D. A. Miller, The Novel and the Police, 79. 
argument I could refer to Dianne Hunter's recent work reading hysteria in terms of dance to suggest how this metaphor already begins to position women in a familiar role. ${ }^{92}$ The use of this metaphor itself waltzes around the issue of the collapse of hysteric and mother, uneasily pairing and separating them in an ever shifting pattern.

Christie McDonald's statement cited earlier about the inevitable duplicity of language comes in an article entitled "Choreographies," a debate about feminism with Jacques Derrida, theorist of that school of criticism against which Foucault-inspired work like Miller's seems directed. Yet feminism is a contested site for Derrida too. In this article, as well as in the later "Women in the Beehive," Derrida emphasizes the contradictions within assuming a feminist position that undermine the ground on which to construct it. Expert at delicate maneuvers, Derrida warns against attempting to freeze the dance of his discourse into one position: "I will go so far as to say that it is to not read the syntax and punctuation of a given sentence when one arrests the text in a certain position, thus settling on a thesis, meaning or truth." 93 But his treatment of feminism has a drift and tenor, if not a truth: although Derrida recognizes a provisional need for the categories of feminism and the institution of women's studies, he recognizes too that the denial of ground for women, although it "is rot anti-feminist, far from it . . . is not feminist either." 94 In his wariness about feminism, Derrida implies an identification between what he calls the "lone dance" of his own ideas and theory and the lone dance he advocates for women, so that they may divorce themselves from the teleology of movements (such as the women's movement); yet for many feminists that very identification and divorce remain wrong notes prompting false steps. ${ }^{95}$ Even those feminists most influenced by Derrida can be disturbed

\footnotetext{
${ }^{92}$ Including, for instance, the recent production of the play, Dr. Charcot's Hysteria Shows (April 1988, Trinity College, Hartford, CT).

93Derrida and McDonald, "Choreographies," 69.

94Derrida and McDonald, "Choreographies," 68.

95Derrida and McDonald, "Choreographies," 68. Derrida's identification of deconstruction with women is well known; in these essays, see, for example, his discussion of the resistance to his ideas which he says "seems to be exactly the same resistance-and there's nothing fortuitous in that-exactly the same resistance which is opposed to women's studies" ("Women in the Beehive: A Seminar with Jacques Derrida," in Men in Feminism, 196). "Women in the Beehive" might be
} 
by his emphasis; the displacement of women privileged in the endless displacements of deconstruction repeats too familiarly the old stresses in which identification means (her) exclusion. ${ }^{96}$

Derrida's identification with and displacement of woman and her discourse waltzes around a discussion of the mother: to McDonald's troubled question about whether a move, by way of hysteria, to collapse the woman with the womb and mother might not involve "essential loss" of other roles and representations for women (a move perhaps repeated by Derrida's writing), Derrida gestures to (and makes use of) the logic of collapse: "Can [one] dissociate them," he asks. Might they not all ultimately mean the same thing, in a kind of sliding chain in which they wind up serving the same end ${ }^{97}$ Just such a question within criticism that explicitly defines itself as feminist has centered around the metaphor of dancing but has reached a different conclusion, in an attempt to articulate the different roles and representations within feminist discourse, as well as its relation to larger critical debate. The necessity of preserving different voices for feminism, the danger of totalizing and reducing it, is, for Annette Kolodny (and for her critics), the only way to negotiate the battlefield of the critical antagonism toward feminism, the only way of "dancing through the minefield." 98

Gilbert and Gubar demonstrate that this silencing of women's

considered one of the more Foucauldian of Derrida's essays; he emphasizes in it (what is implicit in deconstruction) the impossibility of transgression-"deconstruction cannot be transgression of the Law. Deconstruction is the Law. It's an affirmation, and affirmation is on the side of the Law" (197). That he does so in a critique of the way the relation of women's studies to the institution repeats its law, however, suggests the strategic association of women and power that I have been analyzing.

96See, for example, Alice Jardine, Gynesis, 178-207; and Gayatri Chakravorty Spivak, "Displacement and the Discourse of Woman," in Displacement: Derrida and After, ed. Mark Krupnick (1983), 169-95, and "Love Me, Love My Ombre, Elle," Diacritics 14 (1984): 19-36.

97Derrida and McDonald, "Choreographies," 72.

98 Annette Kolodny, "Dancing through the Minefield: Some Observations on the Theory, Practice, and Politics of a Feminist Literary Criticism," Feminist Studies 6 (Spring 1980): 1-25. See also Annette Kolodny, "Dancing between Left and Right: Feminism and the Academic Minefield in the 1980s," Feminist Studies 14 (Fall 1988): 453-66. For responses to Kolodny that stress the need for "diversity" and "dialogism" rather than "pluralism," see Judith Kegan Gardiner, Elly Bulkin, Rena Grasso Patterson, and Annette Kolodny, "An Interchange on Feminist Criticism: On 
voices is usually represented through the collapse between the hysteric and mother, and that it can be deadly. In their reading of the fairy tale "Little Snow White" (a tale that exemplifies romantic plots for them), which serves as the introduction to The Madwoman in the Attic, they chart the way the women's roles in that story all get reduced to one figure, mirroring patriarchy's idea of woman-a collapse that also effectively makes that idea seem an actuality by silencing women's writing and suppressing other notions of women: the end of that story, in which the wicked stepmother is made to perform a hysterical dance of death in red hot slippers, her punishment for attempting to be more than the traditional idea of a mother, for stepping out of place, reflects the way feminist scholarship has been made to perform a precarious kind of hotfooting in its attempt to negotiate a place for itself. ${ }^{99}$ This figure of shoes, the question of which shoes feminism should strap on (sensible shoes or elegant pumps?)-a figure, among other things, for which tone it should adopt in its discourse, which attitude it should take in the institution-organizes the discussion between Nancy Miller and Peggy Kamuf about the role of feminism in that institution. This becomes a debate "on the proper place of Women's Studies" should it have a place at all, should it be replaced by gender studies? - a debate ultimately about whether Foucault's ideas can aid us in finding answers. ${ }^{100}$

The answer to that depends on how those ideas are pitched. One of the contributors to Men in Feminism, Andrew Ross, in an earlier essay, "Viennese Waltzes," critiques what he sees as Jane Gallop's precipitous acceleration of "the stately waltz of psychoanalysis."101 Ross counters deconstructive and psychoanalytic claims of subversion with a more Foucauldian emphasis on our implication within

'Dancing through the Minefield,'" Feminist Studies 8 (1982): 629-75; Nina Baym, "The Madwoman and Her Languages: Why I Don't Do Feminist Literary Theory," in Feminist Issues in Literary Scholarship, ed. Shari Benstock (1987), 245-61; and Laurie Finke, "The Rhetoric of Marginality: Why I Do Feminist Theory," Tulsa Studies in Women's Literature 5 (Fall 1986): 251-72.

${ }^{99}$ Gilbert and Gubar, Madwoman, 36-44.

${ }^{100}$ Nancy K. Miller, "The Text's Heroine: A Feminist Critic and Her Fictions," 49; see also Peggy Kamuf, "Replacing Feminist Criticism," 42-47, both in Diacritics 12 (1982).

${ }^{101}$ Andrew Ross, “Viennese Waltzes," Enclitic 8 (Spring/Fall 1984): 80. Ross seems here to be implying that Gallop is caught in the same kind of excess that he criticizes Cixous for excessively celebrating in hysteria (73). 
structures of power: he discusses hysteria (in part through a careful consideration of the effect of tone), to counter the claim for its autonomous expressivity by attending to its utility for a regime, arguing that we shore up power even by dissenting from it. The focus of his indictment of what he calls "a discourse of liberty" that sees itself as exempt is, however, not deconstruction or psychoanalysis but (one kind of) feminism, and part of his point seems to be that "women are not privileged in" oppression. ${ }^{102}$ What is at issue is not whether Ross's points are well taken (many of them are) or even that he too strategically displaces a larger institutional debate onto problems of feminism but, rather, a certain immoderation of his own tone in doing so. His critique of feminism, by rather relentlessly indicting it for elitism and bad faith, without at all acknowledging that his own work too must necessarily to some degree "[fall] foul of the same historical and enunciatory obstacles" for which he critiques it, risks making him as an informed reader of feminism just as damaging to it as the "uninformed opponents" that he worries French feminist strategies will unintentionally empower. ${ }^{103}$

Nor is it really feminism - "the degree to which a feminist voice might be imperiled" - that is at issue in all these essays. ${ }^{104}$ Feminism becomes the site in them for a debate between men that

${ }^{102}$ Ross, "Viennese Waltzes," 80, 76. Ross's specific readings are carefully nuanced (see, for example, his attentive discriminations about the role of the semiotic in Kristeva's writing, 80). Despite his local understandings of the complexities of different feminist positions, and despite some explicit disclaimers (such as "I have been chiefly concerned with one particular trajectory of the feminist rapprochement with psychoanalysis" [8o]), his rhetoric continues to risk totalizing the writers he treats as current "feminism" itself (in formulations, for example, such as "modern feminist theory" [73] or "the feminist version of" [75]). Granted such totalizations are impossible to avoid (my own essay certainly tends to totalize male critics, collapsing their differences into the one particular trajectory I must partially construct in order to examine it; more insidiously, even in the act of explicitly questioning women's relation to totalization, I keep falling into similar shorthand about feminism), but the question is once again the emphasis given to them. It is not surprising that Ross's essays in Men in Feminism partly complicate his position by focusing on the problems of universalizing, although perhaps unfortunate that his discussion of this problem seems explicitly only to indict feminism for it. For a reading of this strategy of projection, see Elizabeth Weed, "A Man's Place," in Men in Feminism, 7177.

${ }^{103}$ For a discussion of elitism, see Ross, "Viennese Waltzes," 75; of bad faith, 80; the phrases I quote appear on pages 77 and 75 .

${ }^{104}$ Ross, "Viennese Waltzes," 78. 
ultimately silences that voice (see the essays by Robert Scholes and Denis Donoghue in Men in Feminism, which also use feminism to critique deconstruction ${ }^{105}$ ); feminism is the necessary but excluded third term that connects the competing men even when they are aware of the construction of that triangulation, a triangle, as Mary Jacobus has shown in "Is There a Woman in This Text?" that underlies theoretical positioning as much as it underlies the positions of the Oedipal scenario. ${ }^{106}$ Despite his recognition of such structures, Miller enacts them in his essay: his suggestions that the hysteric conserves rather than subverts the status quo come in a debate that is in part a maneuver for institutional power, as do Ross's, and continue the same history in which Freud and Foucault make use of her for their own systems.

Miller ends his discussion of The Woman in White not with the hysteric, however, but with the mother, and for him, just as for the heroes in the texts, she reflects his claims. In the sophisticated restatement that Foucauldian criticism allows of the old feminist maxim, "the personal is the political," Miller locates the mother as preserving within the supposedly privatized family the violent homosocial structure it seems to escape, connecting, as different feminists have repeatedly shown they already know she does, the father and son. In addition, the rhetoric her use permits (Miller tells us that "the novel's final tableau" repeats its "prehistory," and "at the end, then, the novel has merely discovered its beginning, in the family matrix"), coming at the end of his own essay, locates her as the symbol not just for the totality of power but also for the totalizing sweep of Miller's own argument and theoretical system. ${ }^{107}$

Such thinking back through the mother-in the sense that she

105Robert Scholes, "Reading Like a Man," in Men in Feminism, 204-18, and Denis Donoghue, "A Criticism of One's Own," in Men in Feminism, 146-52.

106Jacobus, Reading Woman, 83-109.

107D. A. Miller, The Novel and the Police, 189-90. (See also how Miller's rhetoric implicitly connects the mother and power in his discussion of how the network of power engenders a brutal and monstrous norm that the sensation novel is able, for a moment, to reveal [166].)

Significantly, this chapter ("Cage aux folles") does not end here in this totalizing circle but with an autobiographical note, in which the author (casting himself as a hysteric), while relying on the conventional collapse with the mother, at least structurally seems to escape the system described by her too. The consolation of the positioning of (what is by now) the conventional critical afterword, which asserts the critic's own implication in whatever the essay has been critiquing but implicitly 
becomes the screen that confirms and guarantees the thoughts projected on her-is by no means uncommon in feminism either, and, when it appears in responses to feminism, it often marks critical sympathy or even identification: Miller's description of the mother's construction marks out a position very similar to one an avowed feminist might take. But similarity can itself be invidious, as Stephen Heath's pious reference to his own mother in his essay, "Male Feminism," points up. In avowing his feminism, Heath attempts (as he himself admits) to legitimize his own identification with it; he attempts to bypass the theoretical complications that he recognizes within that identification and clinch it for himself as a special case, by telling us that he has been writing while in the hospital, watching his old and (presumably) dying mother. ${ }^{108}$

The ghoulishness of this particular turn to the mother makes visible the threat to feminism (and the appeal to [male] privilege) that can underlie any identification with it. As feminists, we recognize the implicit desire for mastery within supposedly objective and distanced analyses of women: in The Woman in White, Count Fosco's study of the nerves is one of the things that gives him power over women. But we cannot overlook that desire in figures like Laura's uncle, the hysterical Mr. Fairlie, who identify with women's painful inscription within power but who nonetheless, and in fact because of that identification, exercise mastery. Mr. Fairlie's "female" nervousness is the very source of his power over Laura, his excuse to mistreat and neglect her.

And such identification, whether or not explicitly appropriative, shifts the focus of feminism. Not surprisingly, Miller revises and extends Gilbert's and Gubar's discussion of female imprisonment, for example, to restage imprisonment as a male drama. Such a revision relies on the inescapable tautology that, within phallocentrism, all dramas are male, but the way we accept that insight can more or less effect the male order's continuance. Simply to stop

undermines that assertion somewhat by making it anterior to the argument of the essay, is certainly not an element of this essay's alone (see, for example, my own afterword) and only reveals one of the compromises we make with the systems in which we operate in order to continue to operate. What's interesting to me here, however, is how the figure of the mother gets invoked to allow or even sanction such compromises.

108Stephen Heath, "Male Feminism," 30. See Alice Jardine's reaction to this image, "A Conversation: Alice Jardine and Paul Smith," in Men in Feminism, 246-51. 
at that insight flattens out important differences of tone and emphasis that distinguish our response as subjects to the dramas of phallocentrism that control us, the different stakes we have in them. The complaint that women alone are not "history's privileged victims," which feminists have begun to hear quite often lately-in this particular articulation from Frank Lentricchia-is a peculiar red herring, a misdirection that continues the logic of oppression these critics wish, as feminists do, to unravel. It is not constructed by them just because they are distressed that the "masculine" may become an "expendable afterthought" -although such distress may be a factor-but perhaps because the impossibilities of articulating our relations to power as subjects make falling back on particular available representations a temporary relief - and the conventional fantasy of the mother has been to make her provide such comfort at the same time that she stands for the very disciplinary tactics that exhaust us. Lentricchia's criticisms appear, for example, just after he has conjured a scene of a young "wave of feminists who are at the verge of open revolt against their mothers," an identification perhaps prefiguring and displacing his own desire for (the lost possibility of) revolt. ${ }^{109}$

Critics such as Edward Said and Paul Bové have cautioned that the recent analyses of power by Foucault and his followers serve actually to institutionalize it further-the logical conclusion of Foucault's reasoning, of course, although it's important to recall that he never pushes it as far as some of his critics, and followers, have-and Said suggests that the only way out of that circle is to break it, to reject Foucault on power. ${ }^{110}$ If (rather than forgetting Foucault) we did for a moment want to push him so far and use his

${ }^{109}$ Frank Lentricchia, "Patriarchy against Itself-The Young Manhood of Wallace Stevens," Critical Inquiry 13 (1987): 774. For responses to this essay see Donald E. Pease, "Patriarchy, Lentricchia, and Male Feminization," 379-85; Sandra M. Gilbert and Susan Gubar, "The Man on the Dump versus the United Dames of America; or, What Does Frank Lentricchia Want?" 386-406; and Frank Lentricchia's reply, "Andiamo!" 407-13-all in Critical Inquiry 14 (1988). See also Melita Schaum, " 'Ariel, Save Us': Big Stick Polemics in Frank Lentricchia's Ariel and the Police," Genders 4 (March 1989): 122-29.

It's worth emphasizing again that the problem with criticisms of feminism like Lentricchia's is not that they are wrong (although they may be in many places) but that they are so curiously misguided.

110Edward Said, "Traveling Theory," Raritan 1 (Winter 1982): 41-67. Paul A. Bové discusses how Said's dismissal of Foucault is part of his own ploy for institutional power, in Intellectuals in Power: A Genealogy of Critical Humanism (1986), 209-37. 
work to trace such circles, it would be because, viewed from a feminist perspective, they describe so well the frustrations feminists all know-the spiral of repetitions and reappropriations that results as we try to resist a system we cannot imagine how to overcome-and to deny that structure could be a wish that also tends to blunt the possibility of any resistance. I don't want to go so far, however, if only because arguing about whether this spiral has a limit somewhere can be one way of ignoring our immediate engagement in power struggles. Our arguments may be more helpful to us as feminists if we make them more local and specific-if we focus, for example, on the way that women's engagement in power struggles hasn't always seemed a given and doesn't yeton the way women (or their discourse) are still used to facilitate struggles that try to exclude them from any active part.

Biddy Martin observes that pressing Foucault to his logical limits misses the point in a way particularly harmful to feminism, dispensing with both the category of woman and her oppression: "There is the danger that Foucault's challenges to traditional categories, if taken to a 'logical' conclusion, if made into imperatives rather than left as hypotheses and/or methodological provocations, could make the question of women's oppression obsolete."111 Foucault may be more closely involved in these imperatives than Martin suggests, although Naomi Schor, in her article, "Dreaming Dissymmetry," makes a persuasive case for Foucault's reintroduction of women and of gender as a determining category in the later volumes of The History of Sexuality: nevertheless gender differences do seem problematic, if not elided, in that work. ${ }^{112}$ Different feminists have begun to consider the various elisions or appropriations of the category of woman in recent literary criticism; Lynda Boose and Marguerite Waller provide accounts of how the new historicism has finessed difference and preempted feminism in Renaissance scholarship. ${ }^{113}$ Such analyses help keep

111Biddy Martin, "Feminism, Criticism, and Foucault," in Feminism and Foucault: Reflections on Resistance, ed. Irene Diamond and Lee Quinby (1988), 17. This anthology contains essays on the relations between feminism and Foucault-inspired interpretation in various fields. Such explicitly feminist considerations of Foucault's work itself will aid our different kinds of feminism in examining how his ideas are put into practice, revealing whether or not they are simplified when used.

112Schor, "Dreaming Dissymmetry," 106-10.

${ }^{113}$ Lynda E. Boose, "The Family in Shakespeare Studies; or, Studies in the Family of Shakespeareans; or, The Politics of Politics," Renaissance Quarterly 40 (Winter 
feminists aware and wary of the effacement of gender within the institution that Foucauldian criticism seems to imply, as it repeats the old call for the replacement of women's studies departments with gender studies. They outline the ways that, although Foucauldian criticism seems best at focusing on local and specific contexts and implicating the critic within power relations, by effacing gender distinctions and ignoring how specific male subjects in specific contexts may profit from feminism (or exploit it for nonfeminist or even antifeminist ends), its curiously unself-reflexive appropriations of feminism do neither. As feminists, many of us have up to now focused on the ways that the collapse of gender can be subversive, but we need to focus too on the conservative power of such strategies, the way the collapse between men and women, as between the hysteric and mother, can be a consoling strategy within power that is at the expense of the very feminism that seeks to expose the workings of that power.

Our feminisms can, of course, profit from an analysis that focuses on the way gender and sexuality are constructs in the service of a dominant discourse; such a project may in fact be said to have a feminist impetus. We need as feminists, however, always to insist on recharting that discourse so that its map takes the battles of gender into account. Pip's position within his novel-an orphan delusively free of the mother, of systems of power-may no longer seem available to critics, as it was never truly available to Pip, and that may even turn out to be a victory, one that feminism can partially claim. But such a change may be too easily reabsorbed within power if critics attempt to take the position of Walter Hartright, a favored son, who, if not exempt from, at least is cozy with, the dominance he orecognizes. Feminism needs more than ever to insist on the specificities within it, and to foreground the nuances of women's construction that make madwomen and mothers different, rather than to give in to a totalization of gender that makes feminism another blank page on which we write the same old story.

1987): 707-42; Marguerite Waller, "Academic Tootsie: The Denial of Difference and the Difference It Makes," Diacritics 17 (1987): 2-20. For other readings of new historicism, see Carolyn Porter, "Are We Being Historical Yet?" South Atlantic Quarterly 87 (Fall 1988): 743-86, and Judith Newton, "History As Usual? Feminism and the 'New Historicism,'" Cultural Critique 9 (Spring 1988): 87-121. 
My reading of the hysteric and mother unfolds my own story too, of course, with its desires and claims for the power of my position. My approach here has remained trapped in the imaginary circuit of rivalry and identification, and I have to a greater or lesser degree simply continued the gesture I have analyzed; despite my attempt to attend to the nuances of these differently inspired critics, I have collapsed them into a single Foucauldian monolith (and not only is Foucault's inspiration registered much differently in the work of Miller and Lentricchia, for example, but other subtleties between them as readers make them respectively much more and much less valuable to feminism). One feminist response to this repetition of what I have just criticized might be to say that to have hysterics and mothers reflect a story that emphasizes the woman's position (the point of view of the woman critic, for example) makes a difference and undoes claims for power, because the tale it tells is about the impossibility of that position. Another response might be that it is actually well and good for a woman to claim a role in what have been male power struggles up to now, to make her way into an (old boy's) network of power. If I wanted to be overly reductive, I could identify these voices as the two poles my argument has been working between - the voice of the hysterical subject, recognizing, and perhaps overplaying her lack of autonomy paradoxically as a way out, and the voice of the controlling mother, perhaps wishfully intent on identifying with the system. Although I am sympathetic to both of these stances-who wouldn't wish to elude or control power?-I don't want to settle for them: what I have tried to suggest instead is the danger of wishful satisfactions, the consolations offered by totalizing systems that such neat images of women represent in miniature and draw us back into. Indeed, such responses seem satisfactory because they can be represented, made to fit familiar images of women. Yet the great strength of feminism, I think, (whatever its relation to power) has been in complicating and refusing familiar images. In doing so, feminism allows another response-an uncomfortable because undefined role (neither hysteric nor mother) that we continue to try to take even as we can't describe it-in which we don't attempt to elude or control power, but recognize our implication in it, and go on. 